\title{
Role of Technology Transfer, Innovation Strategy and Network: A Conceptual Model of Innovation Network to Facilitate the Internationalization Process of SMEs
}

\author{
Serena Mancini*, José Luis Calvo González \\ Facultad de CC. EE y EE,Universidad Nacional de Educación a Distancia (UNED), Madrid, Spain \\ Email: *smancini3@alumno.uned.es, jcalvo@cee.uned.es
}

How to cite this paper: Mancini, S., \& Calvo González, J. L. (2021). Role of Technology Transfer, Innovation Strategy and Network: A Conceptual Model of Innovation Network to Facilitate the Internationalization Process of SMEs. Technology and Investment, 12, 82-128.

https://doi.org/10.4236/ti.2021.122006

Received: December 24, 2020

Accepted: May 8, 2021

Published: May 11, 2021

Copyright $\odot 2021$ by author(s) and Scientific Research Publishing Inc. This work is licensed under the Creative Commons Attribution International License (CC BY 4.0).

http://creativecommons.org/licenses/by/4.0/

\begin{abstract}
The purpose of this research paper is to increase the understanding on how the combination of technology transfer and innovation strategy has become key elements for ensuring the development and growth of SMEs since has enhanced their ability to be part of networks and has facilitated their access to international markets. We see that SMEs can balance their limited resources with careful participation in networks. Indeed most SMEs need to be part of networks to get their innovations and develop special competence on technology transfer and to rapidly access to international markets. Although there exists a well-developed tradition of industrial network research there is a lack of analysis of systematic and empirical models of network relating to the technology transfer and innovation strategy in the context of SMEs' internationalization. Based on our research framework on theoretical insights from technology transfer's topic and its extensive concepts of innovation, network and internationalization, we examine how the internationalization process is facilitated by SMEs' networking capacity. Our findings allowed us to address an empirical study created to develop a systematic conceptual model of an innovation network and propositions regarding the access of SMEs to international markets. This model can be an easy-to-follow innovation model for SMEs when adopting a knowledge-transfer, innovation strategy, and networking approach. This helps to make certain that the important drivers and approaches for the innovative network capacity and internationalization performance of SMEs. These findings have critical implications for entrepreneurs in enhancing their firms in international performance. More specifically, we analyze how SMEs' membership in networks or clusters stimulates the concrete collaboration with High Education Institutions (HEIs) or Public Re-
\end{abstract}


search Institutions (PRIs), Governments, and other businesses and contribute to acquire and absorb innovation via different channels of external knowledge influencing SMEs' behaviours at the international level.

\section{Keywords}

SMEs, Technology Transfer, Innovation, Networks, Internationalization

\section{Introduction}

Small and medium-sized enterprises (SMEs) have been drawing the attention of numerous researchers by gambling active positions in international markets during the current years. SMEs have rapidly increased their positions in global markets and used international diversification as an essential strategic choice for growth. The contribution of SMEs to innovation has expanded in ongoing decades because of changes in the way innovation intervenes in the economy (OECD, 2017). SMEs innovation is never again constrained to corporate R \& D labs but is the result of collaborative and synergistic efforts wherein organizations interact and exchange knowledge and information with different partners as part of broader innovation frameworks. The SMEs' innovative potential and introduction of new strategies of production have been considered the key elements for development (Schumpeter, 1934) but it has not been clarified immediately where those new techniques come from (Antonelli \& De Liso, 1997). Transfer of technology has been used to solve this issue while innovation strategy has been indicated as the driver for the economic growth (Dutta, Lanvin, \& Wunsch-Vincent, 2014; OECD, 2007; Van de Ven, 1986). Indeed technology transfer and innovation strategy are recognized as essential elements for SMEs' objectives achievement ensuring growth, sustainability, and competitiveness. They are completely broad concepts and involve many distinct stakeholders varying from governments and scientists to business executives, advertising and marketing experts, and consumers. Technology transfer and innovation strategy have been accreditated within different fields of research (Mom, Oshri, \& Volberda, 2012; Dasgupta \& Taneja, 2011; Morrissey \& Almonacid, 2005; Kneller, 2001; Grotz \& Braun, 1993) as well as within the regulation and policy planning documents (Association of University Technology Managers, n.d.; European Commission, 2010a; European Commission, 2010b). The diversity of the associated parties results in exceptional perspectives of technology transfer and innovation strategy, thus resulting in distinct know-how of both concepts. Their major strategic objective is to foster scientific excellence, innovation, collaboration, and a multidisciplinary method to investigate in numerous fields and technologies, and to make certain long-term recognition in the European environment. In particular science-driven sectors (e.g. biotech), small businesses are frequently the supply of radical innovations, thanks to their flexibility and their potential to work out of dominant knowledge paradigms (OECD, 2017). Even 
though SMEs are a key element of the chain that transforms knowledge management into new products, processes, and services, faced with increasing competition on the internal and global markets, they need to increase their knowledge and research intensity, improve the way they exploit the results of research, expand their business activities to larger markets, and internationalize their knowledge networks. The priority is to help increase the competitiveness of SMEs by funding research and development activities in cooperation with public and private performers of research (High Education Institutions (HEIs), Public Research Institutions (PRIs), governments, technology institutes, and industry) (Intarakumnerd \& Goto, 2018). There are no restrictions in terms of research topics (bottom-up approach), provided the research meets the needs of the SMEs involved and has a clear potential for exploitation. The principle is as follows: qualified research institutions (e.g. HEIs, PRIs) work with SMEs and associations of SMEs to develop solutions for the SMEs' problems. The growing number of technology transfer and innovation strategy studies and the development of different kinds of theories and models, typologies, and taxonomies proposed, forming different relationships between these concepts. Taking into account the relevance of technology transfer and innovation strategy, the purpose of this research paper consists of developing a model of innovation network for SMEs based on the analysis of secondary data from a series of studies and focus group discussions in the domain of technology transfer and innovation strategy. In this context, the networking and internationalization capacity of SMEs is a complex process that is based on the company innovation strategy and a series of techniques of technology transfer management. Accordingly, the following research question was developed: How technology transfer and innovation strategy can facilitate the networking and internationalization capacity of SMEs?

The remainder of this research paper is organized as follows. Section 2 examines the research methodology; Section 3 introduces the previous literature on technology transfer, innovation strategy, network, and internationalization; Section 4 presents conceptual framework and characteristics of the IN model, and examines what role the model can play in the implementation of SMEs networking and internationalization. Section 5 analyses case studies of clusters from Italy and Spain and applies the IN model to these clusters. Finally, Section 6 summarizes the findings in light of relevant literature and concludes the potential of the model of an innovation network for SMEs.

\section{Research Methodology}

1) Research Purpose

According to the constructs identified in the literature review, the theoretical framework developed in this research paper aims to gain a better understanding of how the combination of technology transfer and innovation strategy has become key elements for facilitating networking and internationalization capacity of SMEs since very few studies might have been done to comprehend the phenomenon. The systematic search of the literature, review of technology transfer, 
innovation strategy, network and internationalization definitions, and focus group discussions were utilized in this research paper as research methodologies. More specifically, we have developed this study taking into account three fundamental categories of purpose: exploratory, descriptive and explanatory (Masum \& Fernandez, 2008).

- Exploratory: the exploratory research purpose started from the assumptions that very few studies have been completed (Yin, 2003) but very few studies might have been developed to understand the phenomenon of interest. For this reason, we have built a preliminary painting to give a comprehensive overview of the matter (Sekaran, 1992). The exploratory studies helped us to formulate hypotheses and suggested feasibility since they "are thus important for obtaining a good grasp of the phenomena of interest and for advancing knowledge through good theory building" (Sekaran, 1992). In this research paper, we have been focused on "what" questions.

- Descriptive: the descriptive research purpose has been used to explain the relevant aspects of the phenomenon of interest (Sekaran, 1992) of a certain group in organizations. In this research paper, we have been focused on "how" and "who" questions.

- Explanatory: the explanatory research purpose is based on previous theories and knowledge to point out the patterns related to the phenomenon of interest and to answer the research questions (Yin, 2003). It involved formulating hypotheses and testing them empirically to identify potential relationships between the elements related to the phenomenon of interest. In this research paper, we have been used theory and focused on "why" questions.

Generally, only one of these three categories of research is utilized as the dominant purpose. However, since the purpose of the study is to benefit a higher knowledge of the networking and internationalization aptitude of SMEs combined with technology transfer and innovation strategy, we have applied mainly an explanatory purpose and to some extent exploratory and descriptive.

2) Research approach

Based on our practical experience and review of definitions the possible research question revealed. To confirm the importance and validity of this question, the desk research, case studies and reports, focus group discussions and observations (Quinn, 2002) of SMEs and University experts in public organizations, associations and conferences were applied as a qualitative research approach in all part of this theoretical framework. This research approach has permitted to have a complete and detailed description of the subject through the application of reasoning (Masum \& Fernandez, 2008) and to understand the phenomenon. This approach was helpful to look at theories and construct a systematic conceptual model to link the theories and practices and to fulfill the objectives of the study.

3) Research strategy

The systematic search of the literature review of technology transfer, innovation strategy, network and internationalization definitions and focus group dis- 
cussions were used as a research strategy. On one hand, the review of definitions and our practical experience was revealed the possible research investigation; on the other hand, the qualitative research approach based on the focus group discussions was applied in all parts of the research paper to confirm the significance and validity of our questions as well as to verify discovered links between technology transfer and innovation strategy and SMEs' networking capacity which facilitates the access to international markets.

- Systematic search of the literature: According to (Booth, Papaioannou, \& Sutton, 2012) who argue that every review has to be more or less systematic. In this research paper the systematic search approach (Grant \& Booth, 2009) was chosen to collect data using different kinds of typologies and taxonomies of technology transfer, innovation strategy, network and internationalization. We decided to use this approach because the reviewing literature allows identifying the connection between ideas and practices as well as synthesizing and gaining a new perspective (Randolph, 2009). Each study indicates the state of the technology transfer and innovation strategy in the respective European member states with regards to SMEs' membership in networks or clusters and its art of internationalization capacity. We conducted a thematic analysis of these empirical studies to identify patterns and categories by theme summarising all the views and theories collected. Using different words, we analysed the completed reports to identify patterns, differences, inhibitors to internationalisation, and first-rate practices.

Definitions: The total systematic search is the product of previous draft desk researches conducted to outline and precise the keywords as well as the criteria for inclusion and exclusion of literature. The sources of information have been data from statistical offices (national, Eurostat, OECD, EPO, etc.), companies' annual financial reports, experts' opinions, published reports and scientific papers, commercial databases (e.g., Scopus and Compustat). The following inclusion criteria have been used for the evaluation of this study: 1) literature assessment reporting technology transfer typology(ies) or taxonomy(ies), 2) literature overview reporting innovation strategy typology(ies) or taxonomy(ies); 3) literature evaluation reporting network; 4) literature assessment reporting internationalization; the publication language-English.

Focus group discussions: According to (Gill, Stewart, Treasure, \& Chadwick, 2008) approach, the focus group discussions were applied for generating information on collective views and meanings that lie in the back of the perspectives. They were used as a qualitative research method to confirm the significance and validity of authors' questions and the observed links between technology transfer, innovation strategy and, network and internationalization. Therefore, the data for this research were collected through face-to-face semistructured focus group discussions with individuals from 64 representatives of entities cover 12 different thematic areas in the health \& life sciences fields (52 SMEs, 4 HEIs and 8 PRIs). The topic in the main focus group discussions was developed according to the analytical framework discussed previously. The 
questions covered the following information:

1) General historical background information, where questions related to the past and present of the entities were raised. These questions aimed to pick on the year the entities started its activities, the number of employees at the start and present, size, range of products previously and at present, amount of sales at the start and present, type of customers at the start and present, rate of growth since the beginning, and identification of change of technology projects.

2) Link-specific information on technology acquisition and capabilities draw on measures of technological capability accumulation, details about the main process technology currently in use and other and secondary process technologies that have been transferred previously.

3) Interactions elaborate between domestic and foreign communities moved from the inherent complexity of socio-economic interactions which underlie the generation and exploitation of new technological knowledge. In this perspective, basic steps in the analysis of demand-driven innovation dynamics have involved the identification of the main issues and gaps in the economic literature, and the elaboration of a comprehensive model drawing upon appreciative theorizing.

In addition, they were beneficial in producing a wealthy understanding of participants' experiences and beliefs (Morgan, 1998; Gill, Stewart, Treasure, \& Chadwick, 2008). In this case, the focus group discussions have produced the advantage to use fewer resources (time and money) and the authors have built upon each single response to produce information (Office of Quality Improvement, 2007).

Content evaluation of qualitative data acquired from the focus group discussions was analysed using manual content analysis. The authors of this research paper have turned process data coding in numerous rounds independently to make sure the validity of findings. The resulted were discussed and presented through consensus.

\section{Literature Review}

This section presents the results of a systematic literature review structured around the extensive concepts of technology transfer, innovative strategy capacity and internationalization performance of SMEs which are finalized to develop a systematic conceptual model of an innovation network. The results of the review were then used to conceptualize and identify areas for future research. As a consequence, the data source was articles referring to the manner of intervention, with a few allusions to complementary literature if necessary for clarifying our understating of technology transfer activities.

The literature review has been conducting by using the ScienceDirect, Web of Knowledge and Scopus databases which indexes journals across all disciplines including over 5000 journals within the social science, by identifying the key research outlets focusing on technology transfer and innovation strategy and using a set of keywords (knowledge transfer, network(s), cluster open innovation, knowledge management and processes, internationalization). We have identified, se- 
lected, and analyzed the first group of articles up to the end of 2019 (Secundo, Toma, Schiuma, \& Passiante, 2018). Keywords were selected within the title, abstract, or keywords of articles. The analysis included both journal articles and reviews and returned well over 500 articles. However, we have found that even though the search process was limited to social science journals, a large number of results were related to the natural science definition of network(s) and were therefore no longer applicable to this study. Therefore, to exclude such articles, the second analysis of articles was performed within the initial search using additional keywords for investigating additional terms in every field of the article including the title, abstract and keywords. Reviewing the articles the attention has been paid to some extensive concepts and their connected models and theories. The selection of all articles was performed based on the standards of relevance and quality. On one hand, the title and abstracts of every article were reviewed to ensure that only relevant articles were included from the initial analysis. On the other hand, the journals already represented in a range of literature reviews on technology transfer and innovation strategy were reviewed to guarantee a high-quality selection without eliminating relevant journals within this field due to its niche nature, This procedure allowed verification of the appropriateness of the journals represented on this review which includes the majority of applicable studies related to the topic of interest.

\subsection{Technology Transfer: Definitions and Theories}

DEFINITION: Technology is a term with origins in the Greek technologia, techné (art, skill) + -o- + -logia (words, speech). More specifically it refers to how people satisfy their needs and desires through the systematic study of techniques and use of inventions and discoveries. More generally it means a manner of accomplishing a task especially using technical processes, methods, or knowledge (Carlsson \& Fridh, 2002). A general definition of technology transfer can be constructed by looking at the Latin origins of the word "transfer". (Albors, Sweeney, \& Hidalgo, 2005) state that in Latin, "trans means over, or across the border, and ferre means to carry": the word trans suggests that during the process of carrying, a border is passed meanwhile the concept of carrying refers to something, which is done strongly, on purpose.

The idea of technology transfer-the transfer of the results of research from universities to the economic sector-is stated to have had its origins in a report developed, to the President in 1945 through Vannevar Bush ${ }^{1}$ entitled "ScienceThe Endless Frontier". Having witnessed the importance of university research to the national protection for its role within the successful Manhattan Project, he applied this experience to a recognition of the value of university research as a vehicle for reinforcing the economy by growing the pool of know-how for use by enterprises via the guide of basic science by the federal government. The report ${ }^{1}$ Vannevar Bush held the following positions in government: Chairman, National Defense Research Committee 1940; Director-Office of Scientific Research and Development 1941; Chairman-Joint Research and Development Board 1946-47; Member-Research and Development Board of National Military Establishment 1944-48. 
stimulated great and increasing funding of research by the federal government leading to the established order of several research-orientated governmental agencies, e.g. the National Institutes of Health, the National Science Foundation, the Office of Naval Research, and, ultimately, to the acceptance of the investment of simple research as an important activity of the federal government (Bremer, 1998).

Although technology transfer is not a new business phenomenon, the literature on technology transfer agrees that is difficult to have a specific and univocal definition due to the complexity of the intrinsic process (Robinson, 1991; Spivey et al., 1997). Major theorists have contributed to giving a basic definition of technology transfer, but each has established a role, a definition and a taxonomy that reflect their point of view. The definitions depend on how the user considers technology and in which kind of context (Chen, 1996; Bozeman, 2000): technology transfer can be connected in various fields because has a multidisciplinary nature. It can happen in each area and control of information (Reisman, 2005). (Zhao \& Reisman, 1992) state this has prompted the advancement of various definitions following the control and the reason for the examination.

In the 1980s and late 1990s, the classic literature offers several definitions in respect of technology transfer, which underlines its relevance. Technology transfer has been defined initially as the process whereby technology is moved from one physical or geographic location to another for application toward an end product (Perlmutter \& Sagafi-Nejad, 1981). This transfer can take place either domestically from one sector or firm to another or, it can take place across national boundaries, from one country to another, which is generally accepted as international technology transfer. According to (Gee, 1981), technology transfer is the process by which technology developed for one purpose is utilized either in a very completely different application or by a new user. (Derakhshani, 1983) defines technology transfer as the "acquisition, development, and utilisation of technological knowledge by a country other than that in which this knowledge originated". This definition is similar to that presented by (Van Gigch, 1978). He believes that technology transfer involves the acquisition of "inventive activity" by secondary users. It shows that technology transfer may not always involve the transfer of machinery or physical equipment. (Kaynak, 1985) has outlined technology transfer as the transition of know-how to suit local conditions, with effective absorption and diffusion both within a country and from one country to a different. (Samli, 1985) believes the transfer of technology is the transmission of know-how to suit local conditions, effective absorption, and diffusion each inside a country and from one country to a different. As such, technology is not just one source of growth and vitality for individual enterprises and entire nations, but the central source in many cases. (Fransman, 1986) defines the international transfer of technology as a process "whereby knowledge relating to the transformation of inputs into outputs is acquired by entities within a country 
(for example, firms, research institutes, etc.) from sources outside that country". (Chesnais, 1986) defines technology transfer as the transition of the capability to manufacture a product or process from firms in one country to firms in another. He points out that this transfer includes not only the technical knowledge required to provide the products, but also the capacity to master, develop, and later produce autonomously the technology underlying these products. (Larsen et al., 1986) define technology transfer as the process by which technological innovations are exchanged between individuals and organisations who are involved in $\mathrm{R} \& \mathrm{D}$ on one hand and inputting technological innovations into use on the other hand. According to the definition of (Stewart \& Nihei, 1987) technology transfer is "the utilisation of an existing technique in an instance where it has not previously been used". According to (Meissner, 1988), transfer of technology is the act of sharing know-how by such devices as constancy, joint ventures, gifts, licenses, franchises, and patents. (Aggrawal, 1991) on the other hand, views technology transfer as the communication, adaptation and use of technology from one place or economic region into a second region. He also adds that this technology has to be adapted to local conditions by the receiver to fit its social, political, cultural, economic, and educational environment. (Tyre, 1991) points out that new process introductions often involve considerable problem solving and even innovation at the plant level. The degree of changes in the technology is affected by the attributes and business environments of the units involved in the transfer. Knowledge can also be transferred through training and education, which could include training on how to effectively manage technological processes and changes (Madu, 1992). However the classic literature underlines that the technology transfer concept is considered by several authors as almost impossible (Bozeman, 2000; Zhao \& Reisman, 1992), due to the awkwardness of defining "technology", establishing boundaries in this dynamic process and measuring its impact on individuals, firms or countries. However, the definition of "technology" is not clear (Bozeman, 2000) it was usually considered as a tool (Bozeman, 2000). (Sahal, 1981, 1982) in (Bozeman, 2000) describes technology as a "configuration", stressing the idea that transfer of technology is not just about the product but also about its use and application. (Ramanathan, 1994) underlines that the transfer creates a successful impact if the transferee (receiving unit) takes advantage of the technology transfer. This process of transition includes physical resources, know-how, and technical knowledge (Bozeman, 2000). Based on the analysis of (Osman-Gani, 1999) technology transfer in other cases seems to be utilized to relocating and exchanging of personnel. It has likewise been utilized to show the transfer of technology from the academy to the industry or from an application to a division (Phillips, 2002; Souder et al., 1990; Ramanathan, 1994) points out that the words technology transfer can be used to indicate a process of transition from one unit to another. The economists (Arrow, 1969; Dosi, 1988) analyzed the different applications of technology transfer grounding on properties of generic knowledge to focus on variables that relate to 
product design. From the sociological perspective, the opposite is a proactive process to disseminate or acquire knowledge, experience and related items (Hameri, 1996) but not a free (Autio \& Laamanen, 1995).

In recent work, (Salanță, Beleiu, Mihaila, \& Crisan 2018) analyzed the two words which compose the concept. They consider technology as the process through which an organization transforms work, capital, resources, and data into products and services of extra value which might be a prerequisite for the sole existence of these organizations while transfer encompasses the transference of the proper use. (Vac \& Fitiu, 2017) point out that technology transfer is "the process of designating the formal transfer to industry of discoveries resulting from university or private research, for marketing purposes under the form of new products and/or services". As technology transfer is an active process, it lies at the heart of the process of economic growth (Lin, 2003) and carries across the border of two entities which can be countries, companies, or even individuals (Albors, Sweeney, \& Hidalgo, 2005). Technology transfer is generally supported by mediator organizations such as technology transfer offices (TTOs), university incubators, collaborative research centres, or university technology parks, through which they can engage more actively in knowledge transfer activities (Villani, Rasmussen, \& Grimaldi, 2017). From the demand side, the presence of high-tech firms can help to valorise knowledge produced by universities (Closs, Ferreira, Sampaio, \& Perin, 2012). As partners in technology transfer processes and, simultaneously, as organisations that can make knowledge sharing more effective (De Beer, Secundo, Passiante, \& Schutte, 2017; McAdam, Miller, \& McAdam, 2018) the universities generate and disseminate technology transfer (Brescia, Colombo, \& Landoni, 2016) helping SMEs address the numerous limitations they encounter durin the g innovation process (Kanama \& Nishikawa, 2017). In fact, the technology transfer process has an important role not only for universities and research centres but also for SMEs and economic growth (Dority, 2003). (Garengo, 2019) underlines the importance of the bridging organisation in supporting technology transfer in SMEs since they lack the knowledge and resources to manage the innovation process (Albors, Sweeney, \& Hidalgo, 2005; Eden, Levitas, \& Martinez, 1997). According to this approach, technology is understood as an act of transferring knowledge, skills, technologies, methods, and facilities among industries, universities, other institutions and governments (Intarakumnerd \& Goto, 2018) to allow that scientific and technological growth is accessible to a huge range of users. Additionally, universities play an important role in pushing the development of some territories where they are located (Pugh, 2017) thanks to their contributions to individual firms and for their capability to transfer knowledge and attract skills from other territories.

There are many basic characteristics regarding technology transfer deriving from the above definitions: First, technology has several elements and dimensions and nearly always involves over one component of technology. Numerous components of technology concerned in a very specific case interact with each other as if they constitute a system. Additionally, the technology package should 
be periodically re-evaluated as conditions medication because the project cycle advances, and as new information becomes obtainable. Thus, technology transfer could be a dynamic process. Second, the effective transfer of technology needs adequate infrastructures, which may embody scientific institutions, R \& D facilities, vocational-technical and management training institutes, and skilled personnel of various specialisations, among the recipient country. It conjointly needs an acceptable cultural environment. Both the infrastructure and the cultural environment are basic determinants of the effectiveness of technology transfer. Third, technology developed in a very specific context can hardly ever be introduced into a new environment without at least some degree of modification. Modification and further development of technology are thus very often an integrated part of transfer. This usually involves changing the scale of a production process and the adaptation of products to local market characteristics.

THEORIES: The main objective of this section is to look at a part of the prevalent models of the current Technology Transfer (TT) that have been created throughout the years to support transferees and transferors to understand this process better. The TT process has been examined using diverse techniques. Some TT models were created after World War II to regulate the implementation of TT activities and their commercialization. They are classified in conventional TT models, appropriability models, dissemination models, knowledge utilization models, and communication models. Just later since the mid-1970s, considering the troubles and complexities looked at by managers of technology transfer projects, researchers, experts have been acquainted with new models to encourage the implementation of technology transfer projects. Both qualitative and quantitative models have been proposed. For our research, qualitative models have been analyzed and summarized in Table 1. (Jagoda, 2007) underlines that qualitative models often have as their objective the delineation of activities involved in managing TT and the elicitation of factors that can access the success and/or capability of TT.

\subsection{Innovation Strategy: Definition and Theories}

DEFINITION: To develop a precise definition of Innovation strategy, it is important to define the concept of innovation. Books, journal articles, and business magazine articles on innovation offer a variety of conceptualizations and definitions of innovation. The origin of the word "innovation" comes from the Latin words "innovatio" or "innovo". Both words mean to "renew or to make something new" (Norrman, 2008). The definition of innovation is also highly varied because many different disciplines have focused on innovation from their specific perspective (Baregheh, Rowley, \& Sambrook, 2009). An early definition of innovation, from an economics point of view, was presented by (Schumpeter, 1934) who underlined that innovation, by definition, "had a substantial economic impact. Innovation was something that profoundly changed the marketplace. The innovating organization was, thus, likely to become the new market 
Table 1. Qualitative TT models.

\begin{tabular}{|c|c|c|c|c|}
\hline Year & Author & Range & Key Factors Of The Model & Methodology \\
\hline 1971 & Bar-Zakay & Bar-Zakay Model & $\begin{array}{l}\text { The model is focused on Search, Adaptation, Implementation, } \\
\text { and Maintenance stages. } \\
\text { The model underlines three points: } \\
\text { - There is a need for a comprehensive examination of the entire TT } \\
\text { process from "search" right through to "post-implementation" } \\
\text { activities. } \\
\text { - A process approach must be adopted in planning and implementing } \\
\text { TT projects. } \\
\text { - It is important to have milestones and decision points so that } \\
\text { activities can be strengthened, mistakes corrected, or even the } \\
\text { project terminated at any point in time. }\end{array}$ & $\begin{array}{c}\text { Qualitative } \\
\text { (conceptual model) }\end{array}$ \\
\hline
\end{tabular}

The model has proposed a seven-step process for international technology transfer that might be increasingly important to worldwide partnerships.

The model underlines three points:

- There is a requirement for the transferee to be included right from

1976 Behrman and Behrman and Wallender Wallender Model the earliest starting point in the planning and implementation of a TT project.

- A technology transfer project does not finish with the beginning of production.

- Unless express measures are set up to guarantee the assimilation of the transferred technology, the technology transfer cannot be said to have been effective.
Qualitative

(conceptual model)

\begin{tabular}{|c|c|c|c|c|}
\hline 1980 & $\begin{array}{l}\text { Dahlman and } \\
\text { Westphal }\end{array}$ & $\begin{array}{c}\text { Dahlman and } \\
\text { Westphal Model }\end{array}$ & $\begin{array}{l}\text { The model has proposed a nine-stage process model for the } \\
\text { industrialization process in the Far East. } \\
\text { The model underlines three points: } \\
\text { - } \quad \text { A TT project is best examined utilizing a consecutive perspective. } \\
\text { - } \quad \text { A TT project should be initiated after a feasibility study since } \\
\text { such projects often require substantial commitments. } \\
\text { - Transferees need to create sound engineering and project } \\
\text { management skills without which the TT procedure cannot be } \\
\text { managed effectively. }\end{array}$ & $\begin{array}{c}\text { Qualitative } \\
\text { (conceptual model) }\end{array}$ \\
\hline 1982 & Landau & $\begin{array}{l}\text { General Model of } \\
\text { technology transfer }\end{array}$ & $\begin{array}{l}\text { The model is focused on the transmission of information. } \\
\text { The model considers the promotion of the product as the main factor } \\
\text { for the delivery of the product. }\end{array}$ & $\begin{array}{l}\text { Qualitative } \\
\text { (practical case) }\end{array}$ \\
\hline 1987 & $\begin{array}{l}\text { Schlie, Radnor, } \\
\text { and Wad }\end{array}$ & $\begin{array}{l}\text { Schlie, Radnor, } \\
\text { and Wad Model }\end{array}$ & $\begin{array}{l}\text { The model outlines seven elements that can impact the implementation } \\
\text { and success of any TT project. } \\
\text { The model underlines two points: } \\
\text { - The numerous progressions that have occurred and are } \\
\text { occurring in the worldwide business setting today have made } \\
\text { it basic for managers of technology to increase good insights } \\
\text { into the transferee condition, transferor condition, and the } \\
\text { more prominent condition when developing a TT project. } \\
\text { - The choice of the technology transfer mechanism system } \\
\text { ought to be founded on a modern comprehension of the } \\
\text { other six components. }\end{array}$ & $\begin{array}{c}\text { Qualitative } \\
\text { (conceptual model) }\end{array}$ \\
\hline
\end{tabular}

The longitudinal model of technology transfer is based on a study of developing and industrializing countries.

1988 Lee et al. Lee et al. Model The model points out that a transferee firm needs to put in place strategies to be able to go through the stages of acquisition, assimilation, and eventual improvement. 


\section{Continued}

\begin{tabular}{|c|c|c|c|c|}
\hline 1990 & Keller \& Chinta & $\begin{array}{c}\text { Keller and } \\
\text { Chinta model }\end{array}$ & $\begin{array}{l}\text { The model underlines that successful technology transfer would be } \\
\text { controlled by the degree to which the transferor and transferee deal with } \\
\text { the political, lawful, social, cultural, economic, and technological } \\
\text { boundaries that block transfer and reinforce activities that encourage it. } \\
\text { The encouraging activities allude to the willingness of the partners to } \\
\text { adapt their respective strategic and operational postures to guarantee } \\
\text { a "win-win" result. }\end{array}$ & $\begin{array}{c}\text { Qualitative } \\
\text { (practical case) }\end{array}$ \\
\hline 1998 & Durrani et al. & $\begin{array}{l}\text { Durrani } \\
\text { et al. model }\end{array}$ & $\begin{array}{l}\text { The model presents a conventional approach consisting of five steps: } \\
\text { - Establishing commercial necessities } \\
\text { - Identifying technology solutions } \\
\text { - Classifying technology solutions } \\
\text { - } \text { Establishing sources from where the technology could be procured } \\
\text { The major lesson of this model is that it focuses on the importance of } \\
\text { building up the requirement for a technology transfer project and for } \\
\text { identifying multiple sources of technology for empowering a better } \\
\text { choice of the transferor. }\end{array}$ & $\begin{array}{c}\text { Qualitative } \\
\text { (conceptual model) }\end{array}$ \\
\hline
\end{tabular}

choice of the transferor.

\begin{tabular}{|c|c|c|c|c|}
\hline 2000 & Bozeman & $\begin{array}{c}\text { Effectiveness } \\
\text { model }\end{array}$ & $\begin{array}{l}\text { The model underlines the importance of technology transfer from } \\
\text { universities and government laboratories to industry. In this model, } \\
\text { the key elements of the transfer process are: } \\
\text { - The transfer specialist (the transferor) } \\
\text { - The transfer system } \\
\text { - The transfer object (the content and type of the technology being } \\
\text { transferred) } \\
\text { - The transfer beneficiary (the transferee) } \\
\text { - The demand environment (market and non-market factors vis-à-vis } \\
\text { the requirement for the technology). }\end{array}$ & $\begin{array}{l}\text { Qualitative } \\
\text { (conceptual model) }\end{array}$ \\
\hline 2002 & Malik & $\begin{array}{l}\text { Between areas } \\
\text { of a company }\end{array}$ & $\begin{array}{l}\text { The model is presented for agents of the same institution. The model } \\
\text { describes the positive and negative factors that influence the transfer } \\
\text { process. }\end{array}$ & $\begin{array}{l}\text { Qualitative } \\
\text { (conceptual model) }\end{array}$ \\
\hline 2002 & Mayer \& Blass & University-Industry & $\begin{array}{l}\text { The model presents different approaches that can be used depending on } \\
\text { the characteristics of the agents. } \\
\text { The model describes the importance of a new actor that allows for } \\
\text { "translating" the language spoken by the transmitter and receiver }\end{array}$ & $\begin{array}{c}\text { Qualitative } \\
\text { (practical case) }\end{array}$ \\
\hline 2004 & Rubiralta & University-Industry & $\begin{array}{l}\text { The model presents a systematic approach based on the triplex helix, } \\
\text { where the main agents are the university, as a creator of technology, } \\
\text { the industry, as a receiver of technology, and the technology transfer } \\
\text { office (TTO), as the intermediary agent that supports the transfer process }\end{array}$ & $\begin{array}{l}\text { Qualitative } \\
\text { (conceptual model) }\end{array}$ \\
\hline 2006 & $\begin{array}{l}\text { Gorschek, } \\
\text { Garre, Larsson } \\
\text { \& Wohlin }\end{array}$ & University-Industry & $\begin{array}{l}\text { It is a model built from a particular case. Describes seven steps that } \\
\text { should be taken to achieve technology transfer }\end{array}$ & $\begin{array}{c}\text { Qualitative } \\
\text { (practical case) }\end{array}$ \\
\hline 2009 & $\begin{array}{l}\text { Hofmann, } \\
\text { Amal, \& Mais }\end{array}$ & University-Company & $\begin{array}{l}\text { The model describes that there are three levels that university research } \\
\text { can offer: level of science, level of technology and level of use. } \\
\text { The transfer can occur at any level. }\end{array}$ & $\begin{array}{l}\text { Qualitative } \\
\text { (practical case) }\end{array}$ \\
\hline 2012 & $\begin{array}{l}\text { Khabiri, } \\
\text { Rast \& Senin }\end{array}$ & $\begin{array}{l}\text { Between areas } \\
\text { of a company }\end{array}$ & $\begin{array}{l}\text { It is a model based on the model presented by Malik (Malik, 2002) } \\
\text { where the "great environment" is added; that id, the legislative } \\
\text { environment that influences technology transfer }\end{array}$ & $\begin{array}{l}\text { Qualitative } \\
\text { (conceptual model) }\end{array}$ \\
\hline 2015 & $\begin{array}{l}\text { Bozeman, } \\
\text { Rimes, \& Youtie }\end{array}$ & $\begin{array}{l}\text { General model of } \\
\text { technology transfer }\end{array}$ & $\begin{array}{l}\text { The model considers criteria of effectiveness as a fundamental factor for } \\
\text { the transfer process. In the update of the model presented in 2015, } \\
\text { the value of the public was added as a factor }\end{array}$ & $\begin{array}{l}\text { Qualitative } \\
\text { (conceptual model) }\end{array}$ \\
\hline
\end{tabular}

a. Source: different authors, 2020. 
leader and to gain an immense advantage over its competitors" (Schumpeter, 1943). (Schumpeter, 1934) identified five sources of innovation: the introduction of a new good or a new quality of good, the introduction of a new technique of production, the opening of a new market, the conquest of a new source of raw materials or half-manufactured goods, and the process of reorganizing any industry. Also, (Schumpeter, 1934) emphasized the role compete by the entrepreneur in the innovation process (Freeman \& Soete, 1997). Numerous other successive definitions additionally include the ideas of new and novel: new can be characterized as something that "breaks into" the market or society, while a novel is defined as a new but original, fresh, unique. Some authors focus on innovation at organizational dimension considering it as "the process that includes the generation, development, and implementation of new ideas and behaviours" (Damanpour, 1996) and as a multi-stage process by which an organization transforms an idea into a new or improved product or process, to differentiate itself and compete successfully in the marketplace (Baregheh, Rowley, \& Sambrook, 2009). (West \& Anderson, 1996) point out that "innovation can be defined as the effective application of processes and products new to the organization and designed to benefit it and its stakeholders". (OECD, 2004) defined innovation as, "The introduction of new or improved processes, products or services based on new scientific or technical knowledge and/or organizational know-how." (Mazzarol \& Reboud, 2008) saw innovation as the realization of new products or services, new production processes, new marketing techniques, and new organizational or managerial structures. Innovation may also involve new technology, intellectual property, and business and physical change (Sundbo, 1998; Damanpour et al., 1989; Aiken \& Hage, 1971; Daft, 1982; Zaltman et al., 1973).

(Anderson, Potočnik, \& Zhou, 2014) state that innovation is a new and improved way of doing things, something novel and useful. (Lafley \& Charan, 2008) define it as the conversion of a new idea into revenues and profits. (Freeman, 1982) states the connection among innovation and invention that can be defined as a new idea, model or even physical or service product, whereas an innovation, from a financial point of view, is possibly achieved when the new idea or product achieves its first business progress. If the invention is a new idea that is made a reality, then the innovation is when the invention is applied and adds value. This idea extends the concept of the invention to innovation, as it is no longer only seen as something new or novel, but something new, novel and that provides a company with commercial success. (Baregheh et al., 2009), perfectionated the analysis with an alternative definition of innovation across different disciplines: it could be argued that the specific definition for innovation as a discipline is appropriate. In any case, they concluded that as business and academia become more inter and multi-disciplinary a generic and integrative meaning of innovation is required. Their definition of innovation is: "Innovation is the multi-stage process whereby organizations transform ideas into new/ improved products, service or processes, to advance, compete and differentiate 
themselves successfully in their marketplace".

Recently (Varadarajan, 2018) has presented an overview of definitions and conceptualizations of types of innovation which are indicated in Table 2. (Varadarajan, 2018) discusses the literature and logical underpinnings of the various refinements and proposes a definition of innovation: "Innovation is the creation of value by using relevant knowledge and resources for the conversion of an idea into a new product, process, or practice or, improvements in an existing product, process, or practice".

Building on the above, (Varadarajan, 2018) proposes the following definition of strategic innovation: "Innovation strategy is a firm's relative emphasis on different types of innovations and the associated pattern of resource allocation, in alignment with its strategy at the corporate, business unit and functional levels". Along this line, the planning and implementing of an innovation strategy is a key factor in deciding the dimension of innovativeness, which then drives a firm's financial performance (Crespell \& Hansen, 2008).

As a result, the role and importance of innovation strategy in SMEs have developed significantly (Hamel, 1996). However SMEs have limited resources at their disposal, this lack can be compensated by flexibility, agility, and innovativeness (Qian \& Li, 2003; Acs \& Yeung, 1999). That is why SMEs' performance in various contexts becomes a central issue when discussing the topic of innovation (Mazzarol \& Reboud, 2008; Vermeulen et al., 2005; Wolff \& Pett, 2006). The growth potential effect related to innovation strategy in SMEs comes from three input parameters: technology, R \& D, and generation of competitive edge (Romano, 1999).

THEORIES: Instead of simple innovation theories, several approaches are proposed to deal with the various types of innovation-based predictive variables (Downs \& Mohr, 1976). (Coombs et al., 2003; Powell et al., 1996) point out that innovation strategy is conducted in inter-organizational networks. On the other hand, (Chiesa \& Manzini, 1998) highlight that SMEs progressively moved toward becoming part of networks, in which resources, knowledge, and data circulate quickly and depend on coordinated efforts and partnerships. Knowledge diversity within a network is gainful because it produces positive externalities to multiple agents through knowledge spillovers, opening doors for innovation (Feldman \& Audretsch, 1999; Kogut, 2000). (Gambardella, 1992) states that to be part of a network, and to be able to effectively exploit the data that circulates in the network, has turned out to be significantly more profitable than having the option to produce new knowledge autonomously. (Quinn, 2000) underlines that to contend, collaboration inside a network of partners is becoming essential (Ritter \& Gemünden, 2003), while (Stabell \& Fjeldstad, 1998) presume that the estimation of network increases with its normal size. Interacting with external partners permits a firm to access new knowledge, while network connections appear to advance innovative performance (Caloghirou et al., 2004). (Granovetter, 1973) stresses in terms of network functionality also especially the significance 
Table 2. Innovation and innovation types: An overview of definitions and conceptualizations.

\section{Innovation}

"The implementation of a new or significantly improved product (good or service), or process, a new marketing method, or a new organizational method in business practices, workplace organization or external relations" (OECD, 2005).

Process innovation

"The implementation of a new or significantly improved production or delivery method. This includes significant changes in techniques, equipment and/or software" (OECD, 2005) p. 49.

Product innovation

The process of translating an idea into a customer value proposition that is commercially viable (Chandy \& Tellis, 1998).

"The introduction of a good or service that is new or significantly improved with respect to its characteristics or intended uses. This includes significant improvements in technical specifications, components and materials, incorporated software, user-friendliness or other functional characteristics" (OECD, 2005) p. 48.

Incremental product innovation

An innovation that offers new features, benefits, or improvements in existing technology.

A new product that measures low on both the newness of technology and customer needs fulfilment dimensions.

An innovation that is an adaptation, refinement, or enhancement of an existing product in existing markets

(see (Chandy \& Tellis, 1998; Garcia \& Calantone, 2002)).

An innovation that is a refinement and extension of an established design that results in substantially lower price and/or greater functional benefits to users (Banbury \& Mitchell, 1995).

Radical product innovation

A new product that incorporates a substantially different core technology and provides substantially higher customer benefits relative to previous products in the industry. A new product that measures high on both the newness of technology and customer need fulfillment dimensions (Chandy \& Tellis, 1998).

Market breakthrough product innovation

An innovation based on a core technology that is similar to the technology employed in an existing product that provides substantially higher customer benefits per unit of price paid. A new product that measures low on the newness of technology dimension and high on the customer need fulfillment dimension (Chandy \& Tellis, 1998).

Technological breakthrough product innovation

An innovation based on a substantially different technology compared to the technology employed in an existing product, but does not provide superior customer benefits per unit of price paid. A new product that measures high on the newness of technology dimension and low on the customer need fulfillment dimension (Chandy \& Tellis, 1998).

Business model and business model innovation

A business model is a specification of interdependent activities, processes, and structures that articulate the firm's organizing logic for value creation for its customers and value appropriation for itself and its partners (Sorescu et al., 2011).

A business model innovation is a change in one or more elements of a firm's current business model (content, structure, and governance) and their interdependencies, and thereby, a modification in the organizing logic for value creation and appropriation (Sorescu et al., 2011). A business model comprises four elements: 1) customer value proposition, 2) resources - financial, human, and technological, 3) processes employed to convert inputs into finished products, and 4) profit formula that specifies the margins, asset velocity, and scale required to achieve an attractive return. The interdependencies between the elements of the business model require that each element of the model is congruent with the other elements (Christensen et al., 2016).

"A business model innovation is a new way of delivering and capturing value that changes the basis of competition"

(Nidumolu et al., 2009) p. 60.

Exploitative innovation

Innovations that involve improvements in existing components and build on the existing technological trajectory (Benner \& Tushman, 2002) p. 679.

Technological innovation activities aimed at improving a firm's product offerings in existing product-markets (He \& Wong, 2004) p. 483.

Exploratory innovation

Innovations that involve a shift to a different technological trajectory (Benner \& Tushman, 2002) p. 679.

Technological innovation activities aimed at entering new product-market domains (He \& Wong, 2004) p. 483.

\section{Architectural innovation}

An innovation that entails changes in the way in which the components of a product are linked together, while leaving the core design concepts (and thus the basic knowledge underlying the components) untouched (Henderson \& Clark, 1990). 


\section{Continued}

Reverse innovation

An innovation developed in an emerging market in response to the unique needs of and characteristics of customers in the market, and subsequently launched in relatively more developed markets (Immelt, Govindarajan, \& Trimble, 2009).

Social innovation

"A novel solution to a social problem that is more effective, efficient, sustainable, or just than existing solutions and for which the value created accrues primarily to society as a whole rather than private individuals" (Phills et al., 2008) p. 39.

\section{Sustainable innovation}

"The implementation of a new product, process, or practice, or modification of an existing product, process, or practice by a firm that significantly reduces the impact of its activities on the natural environment" (Varadarajan, 2017) p. 17.

Sustainable product innovation

"The introduction of a new product or modification of an existing product by a firm whose environmental impact during the lifecycle of the product, spanning resource extraction, production, distribution, use, and post-use disposal, is significantly lower than existing products for which it is a substitute" (Varadarajan, 2017) p. 17.

Innovativeness

The capacity of a new innovation to create a paradigm shift in the science and technology and/or market structure of an industry

(Garcia \& Calantone, 2002).

New to: New to the world, new to the industry, new to scientific community, new to the market (place), new to the firm, and/or new to the customer (Garcia \& Calantone, 2002).

New what: New technology, new product line, new product benefits/features, new product design, new process, new service, new competition, new customers, new customer need, new consumption patterns, new uses, new improvements/changes, new development skills, new marketing/sales/distribution skills, new managerial skills, new learning/experience/knowledge, and/or new quality/ benefits (Garcia \& Calantone, 2002).

Product innovativeness

The degree of newness of a product to the firm, its uniqueness of superiority relative to existing products (Cooper, 2001).

The extent to which a product's technology, benefits, and features differ from other products in the same category (Lee \& O'Connor, 2003).

Incrementally new product

A product that better satisfies an existing market need by using existing technologies or refinements of existing technologies (Urban et al., 1996).

Radically new product

A product that shifts the market structure, represents a new technology, requires consumer learning, and induces behavior change

(Urban et al., 1996).

b. Source: (Varadarajan, 2018)

of weak ties, while (Faems et al., 2005) feature the importance of diversity in external relationships to encourage innovation. Network connections, next to intercompany connections, likewise concern linkages among companies and knowledge institutions as recent researches demonstrate the widespread use of university-industry partnerships (Schartinger et al., 2002; D’Este \& Patel, 2007; Meyer-Krahmer \& Schmoch, 1998; Perkmann \& Walsh, 2007). If additionally a governmental body is involved in such a university-industry partnership, the term triple helix collaboration is utilized (Etzkowitz, 2003). Innovation inside networks is extensive as a result of the continued connection among institutions and commercial organizations of different sizes, capacities, and expertise (Omta \& Van Rossum, 1999). A few authors highlight the importance of specific advantages of innovating within networks. Silicon Valley, as an acclaimed case of an innovation network, is professed to upgrade data exchange and to permit new contacts and to build relationships between network members (Saxenian, 1990) and is utilized as standard to analyze other high-tech networks 
against (Bresnahan \& Gambardella, 2004).

\subsection{Network and Networking: Definitions and Theories}

DEFINITIONS: Both terminologies concern the relationships of a business and are used interchangeably in previous literature (Chipika \& Wilson, 2006; Leroy, 2012; Premaratne, 2002; Sawyerr et al., 2003; Scalera \& Zazzaro, 2009, Zain \& Ng, 2006). Network refers to a set of elements or members that are connected (Casson \& Giusta, 2007). Connections or ties are the fundamental features of all networks (Casson \& Giusta, 2007). The connections are the results of relationships between the members. Besides, all members of a network are either directly or indirectly linked to each other (Casson \& Giusta, 2007). Thus, networks consist of a set of elements or members that are connected as a result of the relationships of the members. (Seibert, Kraimer, \& Liden, 2001) define network as "the pattern of ties linking a defined set of persons or social actors". Networking refers to the process of building and engaging in networks. Table 3 below shows that these two concepts appear interchangeably and refer to the relationships of a business.

From these definitions it is evident that there are many relationships which a business can be a member of, therefore, the types of networks vary accordingly.

Table 3. Definitions of networks and networking.

\begin{tabular}{|c|c|c|c|}
\hline Authors & Definition of Network & Authors & Definitions of Networking \\
\hline (Zain \& Ng, 2006) & $\begin{array}{l}\text { A network is the relationships between a firm's } \\
\text { management team and employees with customers, } \\
\text { suppliers, competitors, government, distributors, } \\
\text { bankers, families, friends, or any other party that } \\
\text { enables it to internationalize its business activities. }\end{array}$ & (Lama \& Shrestha, 2011) & $\begin{array}{l}\text { Networking is defined as the process } \\
\text { of building long-term contacts with } \\
\text { the motive to have access towards } \\
\text { information and resources. }\end{array}$ \\
\hline (Nieman, 2006) & $\begin{array}{l}\text { Networks can be defined as patterned, beneficial } \\
\text { relationships between individuals, groups or } \\
\text { organizations that are used to secure critical } \\
\text { economic and non-economic resources needed to } \\
\text { start and manage a business. }\end{array}$ & (Scalera \& Zazzaro, 2009) & $\begin{array}{l}\text { Networking can be formal and } \\
\text { informal links that are created to } \\
\text { allow its members to have } \\
\text { cost-effective economic transactions. }\end{array}$ \\
\hline $\begin{array}{c}\text { (Halinen \& } \\
\text { Törnroos, 1998) }\end{array}$ & $\begin{array}{l}\text { Networks are structures of exchange relationships } \\
\text { among business actors, firms as well as } \\
\text { individuals - structures which emerge, evolve and } \\
\text { dissolve over time in a continuous and interactive } \\
\text { process. }\end{array}$ & (Sawyerr et al., 2003) & $\begin{array}{l}\text { Networking is the link between a } \\
\text { business, its owner or its employees } \\
\text { with other individuals or } \\
\text { businesses, that involves exchanging } \\
\text { of resources. }\end{array}$ \\
\hline (Das \& Teng, 2002) & $\begin{array}{l}\text { Networks are relationships that create connections } \\
\text { between two or more independent entities. }\end{array}$ & (Chipika \& Wilson, 2006) & $\begin{array}{l}\text { Networking is a set of connected } \\
\text { sustained relationships, that involves } \\
\text { cooperation and collaboration which } \\
\text { is mutually beneficial to all members. }\end{array}$ \\
\hline (Premaratne, 2002) & $\begin{array}{l}\text { Networks are long-term contacts between small } \\
\text { business owners and external actors } \\
\text { (persons or organizations) in order to obtain } \\
\text { information, moral supports and other resources. }\end{array}$ & (Nieman, 2006) & $\begin{array}{l}\text { Networking can be defined as } \\
\text { purposefully striving to make } \\
\text { formal and informal contacts and } \\
\text { to form relationships. }\end{array}$ \\
\hline
\end{tabular}

c. Source: Adapted from different authors, 2018. 
THEORIES: Networks have been recognized also as a significant factor in various researches on the innovation process. (Ahuja, 2000; Burt, 1992) have each shown that both the number and structure of connections in networks can improve innovation results. In trying to improve innovation results, effectively overseeing networks can directly lead to better outcomes for firms (Kastelle \& Steen, 2010). While the advantages of managing networks are generally recognized (Malerba \& Vonortas, 2009), there are again open questions about how this knowledge can be applied in the case of SMEs. (Chesbrough, 2006) has demonstrated the importance of networks in open innovation. Firms accomplish and continue open innovation by utilizing a wide range of external actors and knowledge sources (Laursen \& Salter, 2006; Lee et al., 2001; Lichtenthaler, 2009; Poot, Faems, \& Vanhaverbeke, 2009). Even though SMEs contribute significantly to open innovation, they are influenced by the open innovation process in a different way than large firms (Lichtenthaler, 2008). Findings suggest innovation in SMEs is becoming progressively open because of the absence of resources in developing and commercializing new products on their own and as a result, they are increasingly disposed or forced to collaborate with other organizations (van de Vrande et al., 2009). This suggests the immediate impacts of network connections may differ in the case of SMEs. Networks give access to social resources that encourages exploration and exploitation activities of SMEs (Florin, Lubatkin, \& Schulze, 2003; March, 1991). Social capital is in this manner dependent on networks but not equivalent. This is in accordance with hypothesis (Lin, 2008) that network features are exogenous to social capital, but contrary to the view of (Cooke \& Wills, 1999) who point out that “... social capital is the origin and expression of successful network interactions”. We adopt Lin’s interpretation that networks are exogenous to social capital here, leading us to utilize (Nahapiet \& Ghoshal, 1998) definition of social capital as being the "(...) some of the actual and potential resources embedded within, available through, and derived from the network of relationships possessed by an individual or social unit."

The importance of networks and social capital to innovation in SMEs is well documented (Ahuja, 2000; Lee et al., 2001; Rogers, 2004; Zeng, Xie, \& Tam, 2010). The advantages of both intra-firm (Tsai \& Goshal, 1998) and inter-firm networks (Molina-Morales \& Martinez-Fernandez, 2010) are obvious in that social network and related social capital variables were found to add to both product and process innovation in SMEs. Indeed innovation occurs in social networks of actors across multiple contacts (Shane \& Venkataraman, 2000; Burt, 1992). Authors such as (Sullivan \& Marvel, 2011; Thorgren, Wincent, \& Örtqvist, 2009; Schilling \& Phelps, 2007; Rothwell, 1991) support the idea that a more extensive territory and several network ties support innovation performance. The foundation of networks holds a few advantages for SMEs (Robinson, 1982). SMEs typically need economies of scale in research, have less access to data, and other basic innovation resources (Mohannak, 2007). SMEs additionally have in- 
sufficient ability to exclusively manage the entire innovation process and are thusly encouraged to cooperate with other firms prompting potential pooling of resources and data (OECD, 2010). Through establishing network relations, SMEs obtain advantages of large size without its related disadvantages (Nooteboom, 1994; Rothwell \& Dodgson, 1994). Therefore, direct and indirect ties upgrade a firm's access to required contributions to the innovation process including skill accumulation through the combination of correlative skills and collective learning which occurs within networks (Pittaway et al., 2004). (Rosenbusch et al., 2011) challenge the supposition held by the network and social capital works of literature highlighting the importance of inter-firm collaboration and networking in innovation for SMEs. They argue that internal innovation projects lead to greater firm performance than innovation projects with external partners. In fact, they find that "the innovation projects that focus on external collaboration do not increase the performance of SMEs" (Rosenbusch et al., 2011). They attribute this to the "liability of smallness" and "liability of newness" separately alluding to the predominance of greater innovation partners and absence of experience (Edwards, Delbridge, \& Munday, 2005). (Granovetter, 1973) investigation of the strengths of weak ties has opened another line of inquiry into this relationship (Nahapiet \& Ghoshal, 1998). (March, 1991) utilizes this logic to argue that strong ties promote exploitation or the utilization of knowledge while weak ties are essential to new knowledge creation or exploration. Weak ties hamper complex data transfer and strong ties constrain data search in intra-organisational social networks. (Ahuja, 2000) argues strong ties to empower trust (Coleman, 1988, 1990) but limit the diversity of new ideas, while weak ties provide data benefits (Burt, 1992; Granovetter, 1973) but inhibit trust. He concludes that there is no simple and optimal network structure as it is dependent upon the goals of the network members. In addressing this issue, researchers utilized a contingency or dynamic perspective to establish optimal network structures at different phases of the innovation procedure (Fukugawa, 2006; Kleinbaum \& Tushman, 2007; Pirolo \& Presutti, 2010). These outcomes support that weaker ties should be emphasized during the exploration or idea generation phase while strong ties engagement is most proper for innovation implementation or exploitation. Concluding from the theoretical arguments and empirical results, we claim that larger diversity of network ties permits SMEs to draw on additional external resources, enabling them to open up their innovation effort and to innovate across a broader range of activities. We further contend that our measurement of innovation shows that we are taking at exploitation which will benefit most from stronger ties.

Literature has documented the use of different theories on Networking. (Premaratne, 2002) notes that theories on Networking have been guided by several theoretical perspectives such as transaction cost (Coase, 1937; Williamson, 1985), resource dependence (Pfeffer \& Salanick, 1978), relational exchange (Dwyer, Schurr, \& Oh, 1987) agency (Bergh, 1995; Fama, 1980), Social Network 
Approach (Aldrich \& Zimmer, 1986; Birley, 1985; Birley \& Cromie, 1988; Johannisson, 1987; Uzzi, 1997) and international business and marketing (Beije \& Groenewegen, 1992). For our research, the three most relevant theories on networking are summarized in Table 4.

While the connection between networks and performance of SMEs appears obvious from the arguments above, (Rodan, 2010) has argued that innovativeness mediates the connection between network density, knowledge heterogeneity, and managerial performance. At the firm level, networking is an important tool by which SMEs can overcome such challenges. One way in which networking can do this is by helping them achieve economies of scale (Desta, 2015). By growing networks, SMEs can combine based on the industry they are in. The network shaped will assist SMEs to take advantage of economies of scale that might have been not possible for them to achieve if they were to operate individually. Therefore, networking helps SMEs use market opportunities that require large input and output quantities (Desta, 2015).

\subsection{Internationalization Process: Definition and Theories}

The term Internationalization is ambiguous and definitions vary depending on the phenomenon they include. From a historical perspective, the internationalization of SMEs commenced with mankind's ability to travel across the seas and borders. Scholars and academics have attempted to outline internationalization on many activities the use of many different perspectives and variables. (Penrose, 1959) point of view on the subject specializes in the firm's core competencies and opportunities in the foreign environment. (Welch \& Luostarinen, 1988) defined "internationalization as the process in which firms increase their involvements in international operations". By a few scholars, internationalization is also described as "the process by which firms both increase their

Table 4. Theories in the discussion of SMEs networking.

\begin{tabular}{|c|c|c|c|}
\hline Author & Range & Key Factors of the theory & Specific Approach \\
\hline $\begin{array}{c}\text { (Coase, 1937; } \\
\text { Williamson, } \\
\text { 1985) }\end{array}$ & $\begin{array}{l}\text { Transaction Cost } \\
\text { Approach (TCA) }\end{array}$ & $\begin{array}{l}\text { The TCA theory is based on the notion that networking provides } \\
\text { cost-efficient ways of undertaking transactions. Through networking, } \\
\text { SMEs can distribute transaction costs amongst members, thereby } \\
\text { reducing the cost that each business incurs. }\end{array}$ & $\begin{array}{l}\text { Theoretical } \\
\text { approach }\end{array}$ \\
\hline $\begin{array}{c}\text { (Pfeffer \& } \\
\text { Salancik, 1978) }\end{array}$ & $\begin{array}{c}\text { Resource } \\
\text { Dependence } \\
\text { Approach (RDA) }\end{array}$ & $\begin{array}{l}\text { The RDA theory emphasises the notion that businesses may not } \\
\text { have all the necessary human, physical and financial resources to } \\
\text { overcome changes and influences from the external environment. } \\
\text { Therefore, businesses have to depend on one another by creating } \\
\text { networks to access the resources they lack to stay in competition } \\
\text { as well as to grow their business. }\end{array}$ & $\begin{array}{l}\text { Practical } \\
\text { approach }\end{array}$ \\
\hline $\begin{array}{c}\text { (Aldrich \& Zimmer, 1986; } \\
\text { Birley, 1985; } \\
\text { Birley \& Cromie, 1988; } \\
\text { Johannisson, 1987; } \\
\text { Uzzi, 1997) }\end{array}$ & $\begin{array}{l}\text { Social Network } \\
\text { Theory (SNA) }\end{array}$ & $\begin{array}{l}\text { The SNA theory takes into account the social relationships } \\
\text { which business owners come across in running their businesses, } \\
\text { as well as the potential which such interactions have for the } \\
\text { formation of networks. }\end{array}$ & $\begin{array}{l}\text { Practical } \\
\text { approach }\end{array}$ \\
\hline
\end{tabular}

d. Source: (Desta, 2015). 
awareness of the direct and indirect influences of international transactions on their future and establish and conduct transactions with other countries". Later on, (Calof and Beamish, 1995) defined internationalization as "the process of adapting firms operations (strategy, structure, resource, etc.) to international environments".

THEORIES: Most literature in international business shows that export is the principal international business activity to gain access to new and larger markets. Traditionally, internationalization by exporting has been taken into consideration as a manner to increase the growth of firms. Exporting remains significant, but over the past decade, firms have been specializing in exclusive business activities as ways of internationalization and thinking about them to be important to gain competitive advantage. Partnerships with foreign companies, foreign investments and cross border networking have ended up more and more critical as methods of facilitating the alternate of technology and knowledge which allow SMEs to formulate strong international business strategies. Globalization, technological, political and financial changes are some of the main drivers for the growing internationalization of SMEs in today's world. Various theories of internationalization process propose that certain types of SMEs internationalize by following the "U-Model", expressing a careful and modern behaviour; whereas there are different types of SMEs that are considered as born globals and internationalize at an early degree of the establishment. Going back through history we find a lot of theories that approach the internationalization process of the SMEs in different ways. For a complete overview of the SMEs' internationalization process, we have summarized the main theories in Table 5.

Table 5. Theories and models of the SMEs' internationalization process.

\begin{tabular}{|c|c|c|c|}
\hline Author & Range & Key Factors of the theory & Specific approaches \\
\hline $\begin{array}{c}\text { (Johanson \& } \\
\text { Vahlne, 1977) }\end{array}$ & $\begin{array}{l}\text { Uppsala } \\
\text { Internationalization } \\
\text { Process Model }\end{array}$ & $\begin{array}{l}\text { The basic assumption of the Uppsala Model is that market knowledge and } \\
\text { market commitment affects both the commitment decisions and the way } \\
\text { current decisions are performed-and this, in turn, changes market } \\
\text { knowledge and commitment. The amount of knowledge of foreign markets } \\
\text { and operations is influenced by the number of commitments of resources } \\
\text { in foreign markets and vice versa }\end{array}$ & $\begin{array}{l}\text { Theoretical } \\
\text { approach }\end{array}$ \\
\hline $\begin{array}{c}\text { (Johanson \& } \\
\text { Mattsson, 1988) }\end{array}$ & $\begin{array}{l}\text { Network approach to } \\
\text { internationalization }\end{array}$ & $\begin{array}{l}\text { The emphasis of the network approach is on bringing the involved parties } \\
\text { closer by using the information that the firm acquires by establishing close } \\
\text { relationships with customers, suppliers, the industry, distributors, regulatory } \\
\text { and public agencies as well as other market actors. Relationships are based on } \\
\text { mutual trust, knowledge and commitment towards each other. Firm's position } \\
\text { in the local network determines its process of internationalization since that } \\
\text { position determines their ability to mobilize their resources within the network. }\end{array}$ & $\begin{array}{l}\text { Practical } \\
\text { approach }\end{array}$ \\
\hline (Mtigwe, 2006) & $\begin{array}{l}\text { International } \\
\text { Entrepreneurship } \\
\text { Theory (IET) }\end{array}$ & $\begin{array}{l}\text { International entrepreneurship theory argues that individual and firm } \\
\text { entrepreneurial behaviour is the basis of foreign market entry. Technological } \\
\text { advancements, cheap and easy ways to access information and better } \\
\text { communication between the countries have helped SMEs to go abroad. }\end{array}$ & $\begin{array}{l}\text { Empirical } \\
\text { approach }\end{array}$ \\
\hline
\end{tabular}

e. (Masum \& Fernandez, 2008). 
In general, motives to internationalize SMEs are classified as: proactive and reactive (Czinkota, 1982) or pushes and pulls (Bartlett, 1991), which include the same groups of internationalization motives. (Czinkota \& Ronkainen, 2001) state that: "proactive firms go international because they want to, while reactive ones go international because they have to". Before beginning with international activities, a person or thing, regardless of whether from outside or from inside, needs to start the company's international activities (Hollensen, 1998). Proactive (pull factors) motives are inward firms' forces that take the company to the internationalization way, while reactive (push factors) internationalize motives are company reaction to the environment irritations. Proactive processes imply building systematic international strategy. Reactive procedures are spontaneous company's reaction to the alterations in external ambience. Internationalization stimulating factors exist if the company distinguishes business opportunities in foreign business sectors and has exceptional qualities, free operative capacity, the home market is limited, domestic competition presses and empowered by foreign subjects. This internationalization improvement is operational just to the degree that it is conveyed to the attention of the company's decision leaders (Miesenbock, 1988). From the points of initiation of internationalization and who triggers its realization, researchers (Johnston \& Czinkota, 1982; Leonidou, 1988) determine internal (firms) and external (environmental) motivations. Internal motives relate to inside performances of the company, while external motives are connected with the effect of environment (domestic and foreign) on its international activity. Both procedures, internal and external should be solid sufficiently ready to trigger motivation in the decision making in the initialization of export (Cavusgil, 1984). As demonstrated by (Dunning, 1995) there are four different groups of processes in internationalization: 1) market seeking-access to new foreign business sectors; 2) resource seeking access to better and less expensive assets; 3) efficiency seeking access to the assets which improve the level of company's efficiency; and 4) strategic assets seeking access to high technology and core competence improvement.

The process of SMEs' internationalization is additionally full of uncertainties and obstacles, high economic and political risks, requesting generous capacities and assets (Mariasole, Varum, \& Pisicttelo, 2013). In general, small and mediumsized companies, in contrast, to the large ones, have an absence of managerial, financial, organizational and technological assets, which expands the possibility of failure of this process. Given the importance of SMEs and their successful internationalization for national economies, it is of vital significance to the implementation of satisfactory institutional support policies. "Yet the most potent argument in favour of governmental support lies in the fact that SMEs play a key role in the stability and potential of any national economy. They need to be supported to acquire the capabilities needed to compete successfully in the international market" (European Commission, 2007). Therefore, the challenge of any government is to develop such strategy and provide SMEs support mechan- 
ism that will eliminate the obstacles and give incentive for efficient internationalization helping them to incorporate their activities.

\section{Conceptual Framework and Characteristics of the IN Model}

Now that we have covered the important concepts and theories and a literature review of the current literature on technology transfer, innovation strategy, networking/networks and internationalization how they affect internationalization of SMEs, it is time to provide a framework that represents ways of thinking about a study. We believe that by showing a conceptual framework, we can visualize different indicators and how they are interrelated. (Bordage, 2009) defines a conceptual framework as a framework that stems from theories with well-organized principles and propositions that have been confirmed by studies and observations in the field. We believe our study also follows a similar pattern where our conceptual framework resulted from the theories of technology transfer, innovation strategy, networking and internationalization, where both the network forms and the internationalization stage models were confirmed by researchers.

To determine the key issue in the internationalization process of SMEs, explanatory research, including literary analysis was undertaken. Taking a qualitative research approach, we have analysed the main theories outlined in Section 3 so far in terms of how technology transfer and innovation strategy influence SME's networking capacity and their engagement in foreign markets. However, some important considerations have not been adequately addressed in these theories. For this initial research, on one hand, the Triple Helix (Etzkowitz \& Leydesdorff, 1995, 2000) and the Uppsala models (Johanson \& Vahlne, 1977) were used to measure the degree of relations between three actors (government-industry-university) and three variables (technology transfer-innovation strategy-networks); on the other hand, the Connectivity model (Virkkala, Mäenpää, \& Mariussen, 2017) was used to emphasize the increment of entrepreneurial innovation level in the regional interconnected systems.

Triple Helix model repays the breaking points of the traditional linear methodology of innovation where theoretical and practical issues are investigated inside a different institutional field (namely, university and industry) underlining the impact of the transformational changes across institutional boundaries between university, government, and industry, which are viewed as the key players of technology transfer. The focal point is that university, government, and business, which were formerly separated as a prerequisite for the formation of development, have converged to form a unique structural arrangement for improving knowledge-based innovation. Universities are playing the role of business and become more entrepreneurial focused and act as experts (Etzkowitz, 2004). Industries are engaged in more research in new technology development through the foundation of research focuses. The government pushes collaborations among university and industry through planning and imple- 
menting innovation projects (Etzkowitz \& Leydesdorff, 2001). Subsequently, networks are created among the three institutional spheres in common projects for pushing economic growth and knowledge-based innovation.

Uppsala Internationalization Model is utilized to discover that SMEs typically start their expansion in a psychically and culturally close by the market (regional ecosystem). There, they improve knowledge of the market and have more control of assets. Thereafter gradually when SMEs become more experienced and gained better assets, they expand to the more market which is culturally and geographically distant. Furthermore, regularly SMEs entered a new market through export before the establishment of foreign sales subsidiary or foreign production.

Connectivity Model is used to find out the importance of connections in terms of proximity to regional ecosystems where SMEs play a crucial role because interacting through an overlay of networks which are a precondition for the creation of more opportunities for innovative interactions.

Based on the literature review and focus group discussions, and following the Triple Helix (Etzkowitz \& Leydesdorff, 1995, 2000), Uppsala (Johanson \& Vahlne, 1977) and Connectivity (Virkkala, Mäenpää, \& Mariussen, 2017) models, a systematic conceptual model was developed and shown in Figure 1: Innovation Network-IN Model.

Figure 1 describes the theoretical model and shows that the concrete collaboration between Governments, Universities and Businesses (actors) facilitate membership in networks or clusters via different channels of external knowledge (variables) stimulating SMEs' engagement into international ecosystems. Higher is the degree of connectivity between actors and variables, higher is also the level

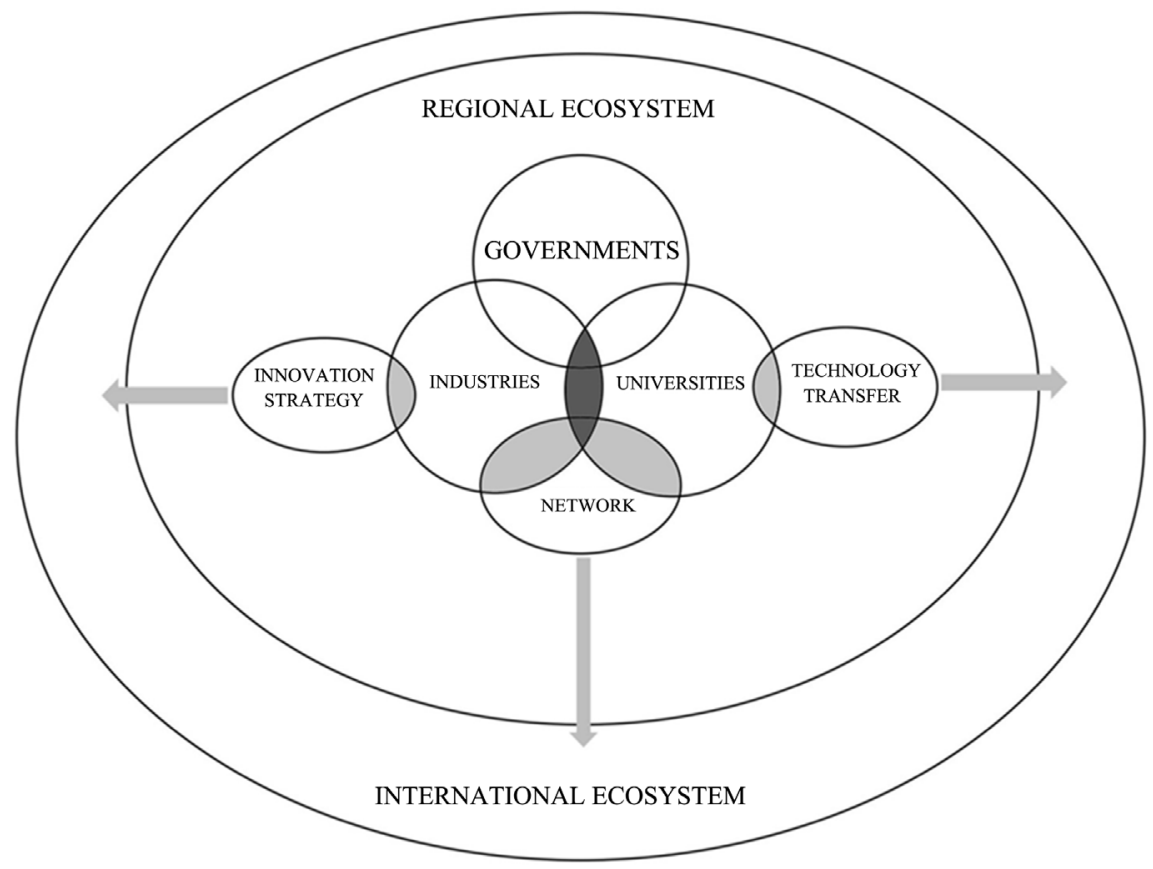

Figure 1. IN model. 
of innovation in the regional interconnected ecosystems due to their contribution to SMEs internationalization process. Our approach to analyzing SMEs internationalization is to use the network as the starting point since it provides an appropriate framework for understanding SMEs as embedded actors in business networks. What follows is an elaboration of the IN Model, first explaining how continuous connectivity between actors and variables reinforces the networking capacity of SMEs and second describing how this connectivity has an impact on their involvement in the international ecosystem. This model falls into the innovation network approach of the firm's internationalization, in line with which an enterprise may internationalize when it develops a set of exchange relationships (Kowalski, 2014). Networking capacity and internationalization analysis of SMEs are the main elements of the Innovation Network model.

\section{Networking Capacity and Internationalization of SMEs}

Connectivity among actors and variables in the regional entrepreneurial system is perceived as a key driver to create conditions for network dynamism of SMEs. The IN model is based on the connectivity among network actors and their necessity to interact between them through external knowledge within the regional interconnected systems; those being technology transfer, innovation strategy and networks. Technology transfer promotes a range of activities that involve researchers, entrepreneurs and technology transfer specialists. These activities include: 1) identifying innovative technologies from numerous sources; 2) selecting and prioritizing technologies; and 3) determining, developing, and applying effective technology transfer methods. Innovation strategy refers to the creation process: how does SMEs create. Innovation must be a fluid process inside any organization. An innovation strategy encompasses a repetitive or iterative process to create. Networks foster inter-enterprise linkages as well as collaborative relations with institutions and local governments. Networks formed by SMEs only are termed horizontal, to distinguish them from those where one or more large-scale enterprises are involved which are of the vertical type. Whether horizontal or vertical, networks can be developed within or independently of clusters. Indeed, the main interest lies in the capacity of developing relational environments favourable to SMEs. These environments are the primary source of opportunity, not only in terms of customers but also in terms of suppliers and partnerships. They allow SMEs to combine their strengths and jointly take advantage of market opportunities.

The continuous connectivity between actors and variables is useful for SMEs by better aligning their entrepreneurial propositions with their stakeholder relationships to value co-creation. When both are at a high level, the relation can be seen as strong, indicating a good solution in terms of access to international markets. Effective co-creation is perceived as even more efficient in the local ecosystem if the SMEs are open to both inflows and outflows of knowledge. When both actors and variable connectivity is low, the relationship is weak. 
When actors' connectivity is high and variables low, there is a development challenge that should raise concerns for international process planners.

High level of connectivity is central in the relationship with all drivers: it is what creates link and synergy in the regional entrepreneurial systems. Connectivity is essential at all stages of the entrepreneurial process, such as generate an innovative idea, communicate it to other parties, materialize it in a successful profitable business and organize a team. These actors and variables are interlinked to generate local SMEs development within regional ecosystems. A strong relationship is might result in closer proximity between the drivers, which again might mean more interaction and a deeper relationship. Moreover, evidence from focus group discussions shows that networking capacity and joint action are more intense when SMEs operate in a regime of connectivity and share business interests such as markets for products, infrastructure needs or challenging external competition. Within such groups or clusters, SMEs' joint initiatives are stronger, because of the critical mass of interested actors, more costeffective due to shared fixed costs and easier to coordinate, with connectivity fostering mutual knowledge and trust. SMEs networking capacity establishes themselves as important and dynamic players within the international systems responding to global competition challenges by capitalizing on local opportunities and collective competitive advantage.

As shown in Figure 1, we have developed the IN model for our study, which summarizes our findings. The model shows that the six major drivers are interacting with one another in the area where lies the international ecosystem and is divided into three parts. Firstly, the interactions are shown between the three actors and three variables also called indicators. As a result of interactions, the SMEs are assisted in networking creation within regional ecosystems. The connectivity between six drivers provides the benefits we described earlier such as market knowledge, market access, trust etc. As a result of these benefits, the network capacity assists SMEs during the phase of internationalization. The IN model aims to show how the networking capacity can influence the access to the international systems of SMEs which then have an impact on connectivity between actors and variables and vice versa.

\section{European Clusters: The Regional Intermediaries for SMEs}

Cluster organisations are legal entities that support the fortifying of collaboration, networking and learning in innovation clusters. They act as innovation suppliers by providing specialised and customised business support services and facilitating strategic partnership across clusters to stimulate innovation activities, particularly in SMEs. "Clusters should be considered as regional ecosystems of related industries and competencies featuring a broad array of inter-industry interdependencies" (Delgado, Porter, \& Stern, 2014). They are defined as groups of firms, related economic entertainers, and institutions (e.g., HEIs or PRIs) that are located near each other and have reached a sufficient scale to develop specia- 
lised expertise, services, resources, suppliers and skills (European Commission, 2016). Cluster initiatives are viewed as a new ecosystem that has opened the path for innovative bottom-up industrial approach strategies and has set up a favourable business environment for SMEs. This thus implies more than merely supporting networking activities and setting up cluster organisations that manage networking and provide support services to SMEs.

The IN model is a result of an investigation research process in which data acquired from the focus group discussions with the relevant stakeholders. The systematic approach of the model consists of content analysis which can be implemented according to the modern cluster policy provided by the concept of Smart Specialisation. The IN model represents a pilot to extend knowledge of the innovative process and to make more interventions in the direction of developing joint roadmaps and aligning investment agendas on relevant topics for innovation policies. It will also serve to encourage entrepreneurs and other organisations such as HEIs and PRIs to become involved in identifying the regions' specialisations.

The different phases of the IN model can be described by utilizing the four principles behind the ideas that SMEs have long been aware of as suggested by the Cluster policy of the European Union. These phases include the original principles from the Smart Guide to Cluster Policy (2016), as well as additions from the IN model.

1) Location principle: the guide underlines that location is the best possible source for SMEs. The interactions that SMEs can achieve with local actors are much richer. The principle of IN Model is the high degree of connectivity between actors and variables push the innovation in regional ecosystems, such as clusters.

2) Linkages principle: an environment that supports active collaboration between SMEs is a principle of the guide. The IN model supports the mobilisation of actors to address common problems through variables and allows mutually beneficial collaboration to emerge.

3) Related industries principle: improving success is a learning and collaborative process that need coordination and organization. The key actors are members of regional ecosystems and clusters which build a collaborative organization and reflect the increasingly cross-industry nature of value chain and innovation systems. These key actors should be included in the coordinated organization trough focus group meetings. In regional ecosystems and clusters, temporary organizational connectivity and shared vision are implemented.

4) Critical mass principle: according to the abovementioned guide, the level of specialisation of SMEs in a certain set of industries is connected to the levels of productivity and innovation. The principle of the IN model is derived from that vision of specialisation which is partly due to competitive pressure on SMEs which is challenging but it makes them more likely to succeed in international and global competition. To formulate a vision of internationalization of SMEs requires more ideas and collaboration to develop unique products and services 
that stand out in the market.

\subsection{The IN Model in Practice: Clust-ER Health (Italy) and Aragón Health Cluster (Spain)}

Emilia-Romagna is one of the northern regions in Italy with about 4.4 million inhabitants. It has a vibrant industrial sector, exemplified by the regional health system in and around the regional capital Bologna. Over 53\% of the value of industrial production was exported in 2019, and Emilia-Romagna has been considered the richest European regions with the third-highest GDP per capita thanks to its innovative and very well balanced economic system. The regional economy is more geared to export markets than other Italian regions: the main exports are from mechanical engineering (53\%), the extraction of non-metallic minerals (13\%) and the clothing industry (10\%). The innovation system of this region is characterized by the efficiency of the health system thanks to the quality of the universities and, a strong and mature industrial sector which boasts the most important biomedical district in Europe. For this reason, the regional authority considers the health and wellness of Emilia-Romagna one of the key sectors for the development of innovation policies. In Emilia-Romagna, a policy model was developed according to this vision around 7 Clust-ERs which work to support the competitiveness of the main production sectors of this region. In the Clust-ERs, the research laboratories and innovation centres of the High Technology Network are integrated with the business system and those of higher education to multiply opportunities and develop high-impact strategic planning regionally. Clust-ERs are key players in the regional innovation ecosystem and they are coordinated by ASTER which is the regional consortium for innovation and technology transfer. In collaboration with local SMEs, the Technopoles, the Laboratories of the High Technology Network, the Innovation Centers and the Training System, contribute to the development of the regional ecosystem.

Clust-ER Health is one of the seven clusters. This cluster was established in 2017 and it brings together 80 members (23 SMEs; 13 LE; 25 among research organisations, universities and technology centres; 16 ecosystem actors) all dislocated in the regional ecosystem. Clust-ER Health covers 4 different Value Chains in the health \& life sciences sectors and ensures continuous industrial innovation, through shared projects between companies, research laboratories, healthcare systems to improve their competitiveness. The regional authority has identified in this cluster a key player in the regional innovation ecosystem capable of multiplying the opportunities for territorial development through the collaborative and participatory approach of its members. According to the international strategy, Clust-ER Health promotes the cooperation and collaboration among its members in the most important scientific and economic events of international importance in the pharmaceutical, biomedical, biotechnology, life sciences and wellness sectors.

Aragón Health Cluster is the health cluster in the region of Aragon (Spain). The cluster was established in 2007 with the main objective to contribute to the 
improvement of competitiveness of the health sector in the regional ecosystem of Aragona to face the internationalization of its members. 37 members in the field of health (21 SMEs; 7 LE; 6 among research organisations, universities and technology centres; 3 ecosystem actors) compose Aragón Health Cluster. Most of them are companies (and particularly, SMEs), and some of them develop activities that are related to the biotech sector. This cluster promotes the collaboration between SMEs and R \& D and knowledge centres, with the support of local public administrations. The activity of Aragón Health Cluster is divided into four fields:

- Innovation. Aragón Health Cluster supports the development of R \& D + i projects between its members, and it tries to help SMEs to identify and get funds to solve their financial needs, which is a critical issue for the development of this kind of projects.

- Networking. Aragón Health Cluster helps its members to contact each other and develop potential business opportunities.

- Training \& Education. Aragón Health Cluster organises courses to solve the particular needs of its members, and helps to contact companies with education providers (Universities, business schools, etc.).

- Internationalization. In the same way, Aragón Health Cluster identifies needs of business development in foreign markets (non-EU) and tries to organize direct or reverse international campaigns to help its companies to contact clients or investors around the world.

Aragón Health Cluster eliminates the barriers to entry to the markets, thus providing its members with the promotion of knowledge, networking and the business by carrying out different actions based on different strategic axes.

\subsection{Discussion on Roles and Success Factors of Clust-ER Health and Aragón Health Cluster}

Even though all two Clusters focus mainly on supporting SMEs, there are differences in mode of interaction with other actors in the regional ecosystems. The Italian Clust-ER Health promotes the integration with the healthcare system involving SMEs within the regional innovation ecosystem and supporting the internationalization of production systems. Aragón Health Cluster has as a priority the definition of technology roadmaps and the promotion of a high impact strategic planning, capable of supporting the competitiveness of the Aragonese regional ecosystem. Interestingly, the intermediary role, especially for its industrial members, at the international level of all two clusters is increasingly significant. Both have been trying to be nodes facilitating network building to help SMEs in various forms especially R \& D consortium and geographical clusters linking SMEs with experts and universities at a regional level. Particularly, Clust-ER Health is an integral part of the regional innovation ecosystem of Emilia-Romagna (Italy) alongside universities and industry research labs. Aragón Health Cluster deals with the internationalization of improving the innovation of its enterprises and the general conditions of the sector in the Aragón regional 
ecosystem.

Success factor of clusters is a big concern among policymakers. Clust-ER Health and Aragón Health Cluster monitor its success in terms of the technology transfer, innovation strategy and networking activities. However, inputs from the industry on management and governance of clusters are necessary to shape the overall strategic direction of them as well as of those of Universities with its research programs to be more relevant to industrial needs. What is also important is the relationship with regional authorities, as these clusters focus on helping SMEs. Finally, both clusters are part of the process of the Intelligent Specialization Strategy (S3), the so-called third-generation regional innovation strategy which has been used by EU as one of the foundations of its cohesion and innovation policy "to ensure the continuous transformation of productive structures through research and innovation, a transformation that concerns the entire regional economy” (Virkkala, Mäenpää, \& Mariussen, 2017) and aims to the internationalization of SMEs through different paths.

\subsection{Evaluation of the IN Model}

The authors acknowledge that each EU Member State's regional innovation ecosystems are different in terms of characteristics of actors, their interaction and underlying institutions. It would be difficult and inadvisable to have a wholesale prescription on how to run clusters successfully. Nonetheless, in practice, clusters have tried to learn from each other. There is also a European Cluster Collaboration platform that organizes annual meetings and training workshops to share experiences among member clusters. From our case studies of two leading clusters from Italy and Spain with a specific mission of supporting the internationalization of SMEs, the authors have drawn the following concluding remarks, theoretical contribution, and policy implications for other clusters in developed countries considering the greatest effect of applying the IN model to those two clusters. The primary results after executing the IN model are as per the following:

1) The analysis regarding clusters' location and objectives which measures the degree of connectivity between actors and variables in the regional innovation ecosystems, provides the relevant information needed for the internationalization process of its members and especially of SMEs. The success stories of Clust-ER Health and Aragón Health Cluster illustrate that to be successful, roles of clusters should fit the nature and level of development of regional innovation ecosystems where they are operating.

2) Focus group discussions helped the authors to understand the bottlenecks in the regional innovation ecosystems. The relationship between clusters and SMEs and non-firm actors, especially, universities became more intense, open, horizontal and longer-term. It is critical for clusters to adopt a more open attitude and to develop capabilities to effectively work with other actors not only in the regional ecosystem. At the same time, it is increasingly important to work 
with actors beyond national borders and taking into account the potentiality of technology transfer, innovation strategy and networking activities. In this way, clusters can pursue internationalization strategies for their members, especially SMEs, to collaborate with actors in both advanced and catching-up countries in the production of new knowledge and exploiting their existing ones.

3) The roles of clusters as "intermediary" are more important to mitigate network failures, or "systemic failures" among SMEs and between SMEs and non-firm actors through mechanisms like R \& D consortium and manufacturing extension programs incorporating local SMEs, experts and universities in different geographical areas.

4) Beyond general interaction with the industry, geographical operation of clusters matters significantly and it is linked to the issue of clusters being knowledge hubs of regional innovation ecosystem. As each geographical area in a region can have different industry specialization, the localization strategy of clusters is necessary. Importantly, the technology transfer and innovation strategy of SMEs with universities and regional authorities as in the cases of Clust-ER Health and Aragón Health Cluster, are a critical factor for networking among the three parties, since it enables face to face-to-face daily interaction.

5 ) Roles of clusters in educating and training human resources are of critical importance. Collaboration between SMEs, university, and regional authorities in research and training of young entrepreneurs, being carried simultaneously by Clust-ER Health and Aragón Health Cluster, is a good example for other clusters.

6) Governments are important to make sure that clusters are relevant to industry and at the same time, maintain research standards. They should provide only a broad direction and evaluate clusters based on short-term indicators like funding from the industry and long-term indicators like contribution on creating new industrial sectors at the regional level.

These outcomes can be seen as useful phases in increasing IN model, which can increase the degree of connectivity between actors and variables. An IN model with structured dialogue between governments, SMEs, and Universities is an approach for entrepreneurial discovery because it helps to improve regional innovation ecosystems by presenting the bottlenecks affecting them and by focusing support on the biggest issues.

\section{Conclusions}

In this section, we discuss our research findings and how it contributes to the theory. Following up, we will describe how further research can be done.

\subsection{Research Findings and Contributions}

The research paper is based on the hypothesis that the increase of the degree of connectivity between three actors (government-industry-university) and three variables (technology transfer-innovation strategy-networks) into regional eco- 
systems can influence the access to international markets of SMEs. In order to find answers to our purpose, we first need to identify the major theories. In addition to the stated main purpose of our research, the investigation has analyzed both definitions and theories. In order to reach this purpose, we have collected information needed to: increase our knowledge on the subject, raise awareness on the previously conducted research, and identify the research gaps.

We have dealt with the research question concerning the role of networking capacity in the internationalization process of SMEs, how to measure connectivity degree between actors and variables into regional ecosystems and how to use these indicators as guides of the internationalization entrepreneurial process. This has been done first by exploring linkages between some actors and variables, and second by building a systematic conceptual model called Innovation Network-IN Model.

The research paper provides a novel approach in which continuous connectivity of some indicators (actors and variables) is at the centre of the IN Model. This was achieved by extending the Triple Helix and Uppsala approach to the Connectivity model to show how the networking capacity of SMEs and the presence in regional ecosystems have an impact on their access to international markets.

We argue that the connectivity between actors and variables, as reinforcement of the networking capacity of SMEs, may be used as a driver of change generated through the internationalization process. The IN Model is especially useful in regions where the degree of connectivity between actors and variables seems to be a problem and the regional administration has a vision of being a connected region. Overall, the IN Model consists of literature reviews, focus group discussions, policy measures, and evaluations; and its identified elements can be replicated.

\subsection{Suggestions for Future Research}

The research paper tried to solve the limitations of dyadic relationships by using the proximity approach in $\mathrm{TH}$ relations in the regional ecosystem where there are many varying actors and also variables. Some of them might be closer than others on different dimensions of proximity. However, there are still limitations in our analysis and more research should be done to facilitate the internationalization process of SMEs. First, the sample of the case studies of two leading Italian and Spanish clusters is diverse in terms of size, location, objectives, and country of origin, which may contribute to a bias in judging their innovation and international strategies. Second, other limitations can be related to the generalisability of the variables as they may not apply to all industrial sectors, but it can be argued that the relationship between actors and variables is being analyzed in-depth, which helps to get a more focused and accurate set of criteria. Finally, the study only looks at SMEs, and therefore the full potential of the variables might not have been exploited.

The IN Model is a soft and gradual approach of Triple Helix, Uppsala and Connectivity models coordinated in multilevel governance. It makes it possible 
to direct specialization and priority seeking in a narrow and specific way, which helps the policy process. It can be possibly combined with other approaches. The IN Model has some bottlenecks that can be addressed, especially by creating more specific methods to evaluate the importance of actors and variables involved in the internationalization process of SMEs. The IN Model was planned for SMEs integrated into regional ecosystems with problems of connectivity with some actors and specific variables. According to the model, new areas and activities can be discovered where perceived gaps might be bridged. These new activities might be smaller entities than the new business areas (domains) that (Foray, 2015) emphasizes as a result of entrepreneurial discovery.

Therefore we propose, for future research to conduct quantitative research. In principle, some companies, throughout Europe, should be analyzed to generalize our results. Moreover, our research has focused on SMEs, however, we think that it can be a theoretical contribution to compare the internationalization process of SMEs to MNEs with the use of IN Model. The results could lead to SMEs growing more rapidly and at a faster pace, both company-wise and internationally. The application of focus group discussions could potentially lead to new technologies cross-fertilization, even unintentionally, when the actors "collide". However, more research is needed on how to combine functional and thematic aspects of the model, such as specific technology or activity that enables the internationalization process of SMEs.

\section{Acknowledgements}

I would like to express my thanks and gratitude to Professor José Luis Calvo González, my tutor, who has provided me with his comments and support throughout the study. Moreover, I would like to thank Mgr. and Mgr. Hana Kosova, Director of the Centre for Knowledge and Technology Transfer of Charles University (Prague, Czech Republic). During my mobility period there, I was able to have a more thorough understanding of the processes of research developments to market, as a channel between academia and industry. This study is supported by the Universidad Nacional de Educación a Distancia-UNED (Madrid, Spain).

\section{Conflicts of Interest}

The authors declare no conflicts of interest regarding the publication of this paper.

\section{References}

Acs, Z. J., \& Yeung, B. (1999). Conclusion. In Z. J. Acs, \& B. Yeung (Eds.), Small and Medium-Sized Enterprises in the Global Economy (pp. 164-173). Ann Arbor, MI: University of Michigan Press.

Aggrawal, R. (1991). Technology Transfer and Economic Growth: A Historical Perspective on Current Developments. In T. Agmon, \& M. Ann Von Glinow (Eds.), Technology Transfer in International Business (pp. 56-76). Oxford: Oxford University Press. 
Ahuja, G. (2000). Collaboration Networks, Structural Holes, and Innovation: A Longitudinal Study. Administrative Science Quarterly, 45, 425-455. https://doi.org/10.2307/2667105

Aiken, M., \& Hage, J. (1971). The Organic Organization and Innovation. Sociology, 5, 63-82. https://doi.org/10.1177/003803857100500105

Albors, J., Sweeney, E., \& Hidalgo, A. (2005). Transnational Technology Transfer Networks for SMEs. A Review of the State-of-the-Art and an Analysis of the European IRC Network. Production Planning \& Control, 16, 413-423. https://doi.org/10.1080/09537280500063434

Aldrich, H., \& Zimmer, C. (1986). Entrepreneurship through Social Networks University of Illinois at Urbana-Champaign's Academy for Entrepreneurial Leadership Historical Research Reference in Entrepreneurship.

Anderson, N., Potočnik, K., \& Zhou, J. (2014). Innovation and Creativity in Organizations: A State-of-the-Science Review, Prospective Commentary, and Guiding Framework. Journal of Management, 40, 1297-1333. https://doi.org/10.1177/0149206314527128

Antonelli, G., \& De Liso, N. (1997). Economics of Structural and Technological Change. London: Routledge.

Arrow, K. (1969). Classificatory Note on the Production and Transmission of Technological Knowledge. American Economic Review, 59, 29-35.

Association of University Technology Managers (n.d.). Bayh-Dole Act. http://www.autm.net/Bayh_Dole_Act1.htm

Autio, E., \& Laamanen, T. (1995). Measurement and Evaluation of Technology Transfer: Review of Technology Transfer Mechanisms and Indicators. International Journal of Technology Management, 10, 643-664.

Banbury, C. M., \& Mitchell, W. (1995). The Effect of Introducing Important Incremental Innovations on Market Share and Business Survival. Strategic Management Journal, 16, 161-182. https://doi.org/10.1002/smj.4250160922

Baregheh, A., Rowley, J., \& Sambrook, S. (2009). Towards a Multidisciplinary Definition of Innovation. Management Decision, 47, 1323-1339. https://doi.org/10.1108/00251740910984578

Bartlett, C. (1991). The Challenges, Motivations, and Mentalities of MNC Management. In J. L. Bower (Ed.), The Craft of General Management (pp. 262-270). Boston, MA: Harvard Business School.

Beije, P. R., \& Groenewegen, J. (1992). A Network Analysis of Markets. Journal of Economic Issues, 26, 87-114. https://doi.org/10.1080/00213624.1992.11505263

Benner, M. J., \& Tushman, M. (2002). Process Management and Technological Innovation: A Longitudinal Study of the Photography and Paint Industries. Administrative Science Quarterly, 47, 676-706. https://doi.org/10.2307/3094913

Bergh, D. D. (1995). Size and Relatedness of Units Sold: An Agency Theory and Resource-Based Perspective. Strategic Management Journal, 16, 221-239. https://doi.org/10.1002/smj.4250160306

Birley, S. (1985). The Role of Networks in the Entrepreneurial Process. Journal of Business Venturing, 1, 107-117. https://doi.org/10.1016/0883-9026(85)90010-2

Birley, S., \& Cromie, S. (1988). Social Networks and Entrepreneurship in Northern Ireland. Paper Presented at Enterprise in Action Conference, Belfast, September 1998.

Booth, A., Papaioannou, D., \& Sutton, A. (2012). Systematic Approaches to a Successful Literature Review. London: Sage. 
Bordage, G. (2009). Conceptual Frameworks to Illuminate and Magnify. Medical Education, 43, 312-319. https://doi.org/10.1111/j.1365-2923.2009.03295.x

Bozeman, B. (2000). Technology Transfer and Public Policy: A Review of Research and Theory. Research Policy, 29, 627-655. https://doi.org/10.1016/S0048-7333(99)00093-1

Bremer, H.W. (1998). University Technology Transfer Evolution and Revolution. The 50th Anniversary of the Council on Governmental Relations.

Brescia, F., Colombo, G., \& Landoni, P. (2016). Organizational Structures of Knowledge Transfer Offices: An Analysis of the World's Top-Ranked Universities. The Journal of Technology Transfer, 41, 132-151. https://doi.org/10.1007/s10961-014-9384-5

Bresnahan, T., \& Gambardella, A. (2004). Building High-Tech Clusters: Silicon Valley and Beyond. Cambridge: Cambridge University Press. https://doi.org/10.1017/CBO9780511802911

Burt, R. S. (1992). Structural Holes: The Social Structure of Competition. Cambridge, MA: Harvard University Press. https://doi.org/10.4159/9780674029095

Calof, J. L., \& Beamish P. W. (1995). Adapting to Foreign Markets: Explaining Internationalization. International Business Review, 4, 115-131. https://doi.org/10.1016/0969-5931(95)00001-G

Caloghirou, Y., Kastelli, I., \& Tsakanikas, A. (2004). Internal Capabilities and External Knowledge Sources: Complements or Substitutes for Innovative Performance? Technovation, 24, 29-39. https://doi.org/10.1016/S0166-4972(02)00051-2

Carlsson, B., \& Fridh, A. C. (2002). Technology Transfer in United States Universities. Journal of Evolutionary Economics, 12, 199-232. https://doi.org/10.1007/s00191-002-0105-0

Casson, M., \& Giusta, M. D. (2007). Entrepreneurship and Social Capital: Analysing the Impact of Social Networks on Entrepreneurial Activity from a Rational Action Perspective. International Small Business Journal, 25, 220-244.

https://doi.org/10.1177/0266242607076524

Cavusgil, S. T. (1984). Organizational Characteristics Associated with Export Activities. Journal of Management Studies, 21, 3-22. https://doi.org/10.1111/j.1467-6486.1984.tb00222.x

Chandy, R. K., \& Tellis, G. J. (1998). Organizing for Radical Product Innovation: The Overlooked Role of Willingness to Cannibalize. Journal of Marketing Research, 35, 474-487. https://doi.org/10.1177/002224379803500406

Chen, M. (1996). Managing International Technology Transfer. Thunderbird Series in International Management, London: International Thompson Press.

Chesbrough, H. W. (2006). Open Innovation: A New Paradigm for Understanding Industrial. In H. W. Chesbrough, W. Vanhaverbeke, \& J. West (Eds.), Open Innovation: Researching a New Paradigm (pp. 15-33). Oxford: Oxford University Press.

Chesnais, F. (1986). Science Technology and Competitiveness. STI Review, Paris: Organisation for Economic Co-Operation and Development.

Chiesa, V., \& Manzini, R. (1998). Profiting from the Virtual Organisation of Technological Innovation: Suggestions from an Empirical Study. International Journal of Technology Management, 15, 109-123. https://doi.org/10.1504/IJTM.1998.002597

Chipika, S., \& Wilson, G. (2006). Enabling Technological Learning among Light Engineering SMEs in Zimbabwe through Networking. Technovation, 26, 969-979. https://doi.org/10.1016/j.technovation.2005.09.014

Christensen, C. M., Bartman, T., \& van Bever, D. (2016). The Hard Truth about Business Model Innovation. MIT Sloan Management Review, 58, 31-40. 
Closs, L., Ferreira, G., Sampaio, C., \& Perin, M. (2012). Factors That Influence the University-Industry Technology Transfer Process: The Case of PUCRS. Revista de Administração Contemporânea, 16, 59-78. https://doi.org/10.1590/S1415-65552012000100005

Coase, R. (1937). The Nature of the Firm. Economica, 4, 386-405. https://doi.org/10.1111/j.1468-0335.1937.tb00002.x

Coleman, J. S. (1988). Social Capital in the Creation of Human Capital. American Journal of Sociology, 94, S95-S120. https://doi.org/10.1086/228943

Coleman, J. S. (1990). Foundations of Social Theory. Cambridge, MA: Harvard University Press.

Cooke, P., \& Wills, D. (1999). Small Firms, Social Capital and the Enhancement of Business Performance through Innovation Programs. Small Business Economics, 13, 219-234. https://doi.org/10.1023/A:1008178808631

Coombs, R., Harvey, M., \& Tether, B. S. (2003). Analysing Distributed Processes of Provision and Innovation. Industrial and Corporate Change, 12, 1125-1155. https://doi.org/10.1093/icc/12.6.1125

Cooper, R. G. (2001). Winning at New Products: Accelerating the Process from Idea to Launch (3rd ed.). Cambridge, MA: Perseus Publishing.

Crespell, P., \& Hansen, E. (2008). Work Climate, Innovativeness, and Firm Performance in Us Forest Sector: In Search of a Conceptual Framework. Canadian Journal of Forest Research, 38, 1703-1715. https://doi.org/10.1139/X08-027

Czinkota, M. R. (1982). Export Development Strategies. New York, NY: Praeger Publishers.

Czinkota, M. R., \& Ronkainen, I. A. (2001). International Marketing (6th ed.). San Diego, CA: Harcourt College Publishers.

D’Este, P., \& Patel, P. (2007). University-Industry Linkages in the UK: What Are the Factors Underlying the Variety of Interactions with Industry? Research Policy, 36, 1295-1313. https://doi.org/10.1016/j.respol.2007.05.002

Daft, R. L. (1982). Bureaucratic versus Nonbureaucratic Structure and the Process of Innovation and Change. In S. B. Bacharach (Ed.), Research in the Sociology of Organizations (pp. 129-166). Greenwich, CT: JAI Press Inc.

Damanpour, F. (1996) Organizational Complexity and Innovation: Developing and Testing Multiple Contingency Models. Management Science, 42, 629-782.

https://doi.org/10.1287/mnsc.42.5.693

Damanpour, F., Szabat, K. A., \& Evans, W. M. (1989). The Relationship between Types of Innovation and Organizational Performance. Journal of Management Studies, 26, 587-602. https://doi.org/10.1111/j.1467-6486.1989.tb00746.x

Das, T. K., \& Teng, B. S. (2002). Alliance Constellations: A Social Exchange Perspective. Academy of Management Review, 27, 445-456. https://doi.org/10.5465/amr.2002.7389937

Dasgupta, P., \& Taneja, N. (2011). Low Carbon Growth: An Indian Perspective on Sustainability and Technology Transfer. Problems of Sustainable Development, 6, 65-74.

De Beer, C., Secundo, G., Passiante, G., \& Schutte, C. S. (2017). A Mechanism for Sharing Best Practices between University Technology Transfer Offices. Knowledge Management Research \& Practice, 15, 523-532. https://doi.org/10.1057/s41275-017-0077-3

Delgado, M., Porter, M. E., \& Stern, S. (2014). Defining Clusters of Related Industries. Working Paper No. 20375, Cambridge, MA: National Bureau of Economic Research. 
https://www.nber.org/papers/w20375 https://doi.org/10.3386/w20375

Derakhshani, S. (1983). Factors Affecting Success in International Transfers of Technology: A Synthesis, and a Test of a New Contingency Model. The Developing Economies, 2, 27-47. https://doi.org/10.1111/j.1746-1049.1984.tb00650.x

Desta, N.T. (2015). Networking as a Growth Initiative for Small and Medium Enterprises in South Africa. Master Disseration, Bloemfontein: University of the Free State.

Dority, M. (2003). Technology Transfer and Its Role in the Commercialisation Process, $A$ Case Study: The University of Missouri. Columbia, MO: Office of Science and Technology. Missouri Department of Economic Development.

Dosi, G. (1988). The Nature of the Innovation Process. In G. Dosi (Ed.), Technical Change and Economic Theory (pp. 221-238). London: Printer Publications.

Downs, G. W., \& Mohr, L. B. (1976). Conceptual Issues in the Study of Innovation. Administrative Science Quarterly, 21, 700-714. https://doi.org/10.2307/2391725

Dunning, J. H. (1995). Reappraising the Eclectic Paradigm in an Age of Alliance Capitalism. Journal of International Business Studies, 26, 461-491.

https://doi.org/10.1057/palgrave.jibs.8490183

Dutta, S., Lanvin, B., \& Wunsch-Vincent, S. (2014). The Global Innovation Index 2014: The Human Factor in Innovation. Geneva: World Intellectual Property Organization. http://www.globalinnovationindex.org/userfiles/file/reportpdf/GII-2014-v5.pdf.

Dwyer, F. R., Schurr, P., \& Oh, S. (1987). Developing Buyer Seller Relationships. Journal of Marketing, 51, 11-27. https://doi.org/10.1177/002224298705100202

Eden, L., Levitas, E., \& Martinez, R. J. (1997). The Production, Transfer and Spillover of Technology: Comparing Large and Small Multinationals as Technology Producer. Small Business Economics, 9, 53-66. https://doi.org/10.1023/A:1007955832161

Edwards, T., Delbridge, R., \& Munday, M. (2005). Understanding Innovation in Small and Medium-Sized Enterprises: A Process Manifest. Technovation, 25, 1119-1127. https://doi.org/10.1016/j.technovation.2004.04.005

Etzkowitz, H. (2003). Innovation in Innovation: The Triple Helix of University-IndustryGovernment Relations. Social Science Information, 42, 293-337. https://doi.org/10.1177/05390184030423002

Etzkowitz, H. (2004). The Evolution of the Entrepreneurial University. International Journal of Technology \& Globalization, 1, 64-77. https://doi.org/10.1504/IJTG.2004.004551

Etzkowitz, H., \& Leydesdorff, L. (1995). The Triple Helix-University-Industry-Government Relations: A Laboratory for Knowledge-Based Economic Development. EASST Review, 14, 14-19.

Etzkowitz, H., \& Leydesdorff, L. (2000). The Dynamics of Innovation: From National Systems and "Mode 2" to a Triple Helix of University-Industry-Government Relations. Research Policy, 29, 109-123. https://doi.org/10.1016/S0048-7333(99)00055-4

Etzkowitz, H., \& Leydesdorff, L. (2001). Universities and the Global Knowledge Economy: A Triple Helix of University-Industry-Government Relations. London; New York, NY: Continuum.

European Commission (2007). Small Enterprise Development in the Former Yugoslav Republic of Macedonia. An Overview. Brussels: European Commission.

European Commission (2010a). Communication from the Commission. Europe 2020. A Strategy for Smart, Sustainable and Inclusive Growth. Brussels: European Commission. http://eur-lex.europa.eu/LexUriServ/LexUriServ.do?uri=COM:2010:2020:FIN:EN:PDF 
European Commission (2010b). Project Europe 2030. Challenges and Opportunities. A Report to the European Council by the Reflection Group on the Future of the EU 2030. Luxembourg: Publications Office of the European Union. https://www.consilium.europa.eu/media/30776/qc3210249enc.pdf

European Commission (2016). Guidebook Series How to Support SME Policy from Structural Funds. Smart Guide to Cluster Policy. Belgium: Publications Office of the European Union.

https://s3platform.jrc.ec.europa.eu/documents/20182/84453/Smart+Guide+to+Cluster +Policy/fd0f16b9-0759-43ca-b950-ec0192e220c8

Faems, D., Van Looy, B., \& Debackere, K. (2005). Interorganizational Collaboration and Innovation: Toward a Portfolio Approach. Journal of Product Innovation Management, 22, 238-250. https://doi.org/10.1111/j.0737-6782.2005.00120.x

Fama, E. (1980). Agency Problems and the Theory of the Firm. Journal of Political Economy, 88, 288-307. https://doi.org/10.1086/260866

Feldman, M. P., \& Audretsch, D. B. (1999). Innovation in Cities: Science-Based Diversity, Specialization and Localized Competition. European Economic Review, 43, 409-429. https://doi.org/10.1016/S0014-2921(98)00047-6

Florin, J., Lubatkin, M., \& Schulze, W. (2003). A Social Capital Model of High-Growth Ventures. The Academy of Management Journal, 46, 374-384.

Foray, D. (2015). Smart Specialisation: Opportunities and Challenges for Regional Innovation Policy. Abingdon: Routledge.

Fransman, M. (1986). Technology and Economic Development. Edinburgh: Wheatsheaf Books. https://doi.org/10.1007/978-1-349-18440-8

Freeman, C. (1982). The Economics of Industrial Innovation. London: Frances Pinter.

Freeman, C., \& Sote, L. (1997). The Economics of Industrial Revolution (3rd ed.). London: Penguin Books.

Fukugawa, N. (2006). Determining Factors in the Innovation of Small firm Networks: A Case of Cross-Industry Groups in Japan. Small Business Economics, 27, 181-193. https://doi.org/10.1007/s11187-006-0010-2

Gambardella, A. (1992). Competitive Advantages from In-House Scientific Research: The US Pharmaceutical Industry in the 1980s. Research Policy, 21, 391-407. https://doi.org/10.1016/0048-7333(92)90001-K

Garcia, R., \& Calantone, R. (2002). A Critical Look at Technological Innovation Typology and Innovativeness Terminology: A Literature Review. The Journal of Product Innovation Management, 19, 110-132. https://doi.org/10.1111/1540-5885.1920110

Garengo, P. (2019). How Bridging Organisations Manage Technology Transfer in SMEs: An Empirical Investigation. Technology Analysis \& Strategic Management, 31, 477-491. https://doi.org/10.1080/09537325.2018.1520976

Gee, S. (1981). Technology Transfer, Innovation, and International Competitiveness. Chichester: John Wiley \& Snons Ltd.

Gill, P., Stewart, K., Treasure, E., \& Chadwick, B. (2008). Methods of Data Collection in Qualitative Research: Interviews and Focus Groups. British Dental Journal, 204, 291-295. https://doi.org/10.1038/bdj.2008.192

Granovetter, M. (1973). The Strength of Weak Ties. American Journal of Sociology, 78, 1360-1380. https://doi.org/10.1086/225469

Grant, M. J., \& Booth, A. (2009). A Typology of Reviews: An Analysis of 14 Review Types and Associated Methodologies. Health Information and Libraries Journal, 26, 91-108. 
https://doi.org/10.1111/j.1471-1842.2009.00848.x

Grotz, R., \& Braun, B. (1993). Networks, Milieux and Individual Firm Strategies: Empirical Evidence of an Innovative SME Environment. Geografiska Annaler: Series B, Human Geography, 75, 149-162. https://doi.org/10.1080/04353684.1993.11879657

Halinen, A., \& Törnroos, J. A. (1998). The Role of Embeddedness in the Evolution of Business Networks. Scandinavian Journal of Management, 14, 187-205. https://doi.org/10.1016/S0956-5221(98)80009-2

Hamel, G. (1996). Strategy as Revolution. Harvard Business Review, 74, 69-82.

Hameri, A. P. (1996). Technology-Transfer between Basic Research and Industry. Technovation, 16, 51-57, 91-92. https://doi.org/10.1016/0166-4972(95)00030-5

He, Z. L., \& Wong, P. K. (2004). Exploration vs. Exploitation: An Empirical Test of the Ambidexterity Hypothesis. Organization Science, 15, 481-494. https://doi.org/10.1287/orsc. 1040.0078

Henderson, R. M., \& Clark, K. B. (1990). Architectural Innovation: The Reconfiguration of Existing Product Technologies and the Failure of Established Firms. Administrative Science Quarterly, 35, 9-30. https://doi.org/10.2307/2393549

Hollensen, S., (1998). Global Marketing: A Market-Oriented Approach. London: Pearson Education.

Immelt, J. R., Govindarajan, V., \& Trimble, C. (2009). How GE Is Disrupting Itself. Harvard Business Review, 87, 55-65.

Intarakumnerd, P., \& Goto, A. (2018). Role of Public Research Institutes in National Innovation Systems in Industrialized Countries: The Cases of Fraunhofer, NIST, CSIRO, AIST, and ITRI. Research Policy, 47, 1309-1320.

https://doi.org/10.1016/j.respol.2018.04.011

Jagoda, K. I., (2007). A Stage-Gate Model for Planning and Implementing International Technology Transfer. Doctoral Thesis, Greater Western Sydney: University of Western Sydney.

Johannisson, B. (1987). Anarchist and Organizers-Entrepreneurs in a Network Perspective. International Studies of Management and Organization, 17, 49-63. https://doi.org/10.1080/00208825.1987.11656445

Johanson, J., \& Mattsson, L. G. (1988). Internationalization in Industrial Systems: A Network Approach. In N. Hood, \& J. E. Vahlne (Eds.), Strategies in Global Competition (pp. 194-213). New York, NY: Croom Helm.

Johanson, J., \& Vahlne, J. E. (1977). The Internationalization Process of the Firm-A Model of Knowledge Development and Increasing Foreign Market Commitments. Journal of International Business Studies, 8, 23-32. https://doi.org/10.1057/palgrave.jibs.8490676

Kanama, D., \& Nishikawa, K. (2017). What Type of Obstacles in Innovation Activities Make Firms Access University Knowledge? An Empirical Study of the Use of University Knowledge on Innovation Outcomes. The Journal of Technology Transfer, 42, 141-157. https://doi.org/10.1007/s10961-015-9459-y

Kastelle, T., \& Steen, J. (2010). New Methods for the Analysis of Innovation Networks. Innovation: Management, Policy and Practice, 12, 2-4.

Kaynak, E. (1985). Transfer of Technology from Developed to Developing Countries: Some Insights from Turkey. In A. C. Samli, (Eds.), Technology Transfer, Geographical, Economic, Culture, and Technical Dimensions (pp. 155-176). Westport, CT: Quorum Books.

Kleinbaum, A. M., \& Tushman, M. L. (2007). Building Bridges: The Social Structure of 
Interdependent Innovation. Strategic Entrepreneurship Journal, 1, 103-122. https://doi.org/10.1002/sej.14

Kneller, R. (2001). Technology Transfer: A Review for Biomedical Researchers. Clinical Cancer Research, 7, 761-774.

Kogut, B. (2000). The Network as Knowledge: Generative Rules and the Emergence of Structure. Strategic Management Journal, 21, 405-425. https://doi.org/10.1002/(SICI)1097-0266(200003)21:3\%3C405::AID-SMJ103\%3E3.0.C $\underline{\mathrm{O} ; 2-5}$

Kowalski, A. M. (2014). The Role of Innovative Clusters in the Process of Internationalization of Firms. Journal of Economics, Business and Management, 2, 181-185. https://doi.org/10.7763/JOEBM.2014.V2.121

Lafley, A. G., \& Charan, R. (2008). The Game-Changer: How You Can Drive Revenue and Profit Growth with Innovation. New York, NY: Crown Business.

Lama, A. K., \& Shrestha, A. K. (2011). Factors Influencing in Networking Activities in SMEs an Exploratory Study of Factors that Initiate Networking Activities in Case of SMEs. Master Thesis, Umea: Umea School of Business.

Larsen, J. K., Wigand, R. T., \& Rogers, E. M. (1986). Industry-University Technology Transfer in Microelectronics. Report to the National Science Foundation, Los Altos, CA: Cognos Associates.

Laursen, K., \& Salter, A. (2006). Open for Innovation: The Role of Openness in Explaining Innovation Performance among UK Manufacturing Firms. Strategic Management Journal, 27, 131-150. https://doi.org/10.1002/smj.507

Lee, C., Lee, K., \& Pennings, J. M. (2001). Internal Capabilities, External Networks, and Performance: A Study on Technology-Based Ventures. Strategic Management Journal, 22, 615-640. https://doi.org/10.1002/smj.181

Lee, Y., \& O'Connor, G. (2003). The Impact of Communication Strategy on Launching New Products: The Moderating Role of Product Innovativeness. Journal of Product Innovation Management, 20, 4-21. https://doi.org/10.1111/1540-5885.t01-1-201002

Leonidou, L. C. (1988). Export Initiation by Indigenous Manufacturers in a Small Developing Country. Spoudai, 38, 63-78.

Leroy, M.T. (2012). The Impact of Networking on Access to Finance and Performance of SMEs in the Buffalo City Municipality, Eastern Cape, South Africa. Master in Business Management, Alice: University of Fort Hare.

Lichtenthaler, U. (2008). Open Innovation in Practice: An Analysis of Strategic Approaches to Technology Transactions. IEEE Transactions on Engineering Management, 55, 148-157. https://doi.org/10.1109/TEM.2007.912932

Lichtenthaler, U. (2009). Absorptive Capacity, Environmental Turbulence, and the Complementarity of Organizational Learning Processes. Academy of Management Journal, 52, 822-846. https://doi.org/10.5465/amj.2009.43670902

Lin, B. W. (2003). Technology Transfer as Technological Learning: A Source of Competitive Advantage for Firms with Limited $\mathrm{R} \& \mathrm{D}$ Resources. $R$ \& D Management, 33, 327-341. https://doi.org/10.1111/1467-9310.00301

Lin, N. (2008). A Network Theory of Social Capital. In D. Castiglione, J. van Deth, \& G. Wolleb (Eds.), The Handbook of Social Capita (pp. 50-69). New York, NY: Oxford University Press.

Madu, C. N. (1992). Strategic Planning in Technology Transfer to Less Developed Countries. New York, NY: Quorum Books (An Imprint of Greenwood Publishing Group).

Malerba, F., \& Vonortas, N. S. (2009). Innovation Networks in Industries and Sectoral 
Systems: An Introduction. Chapters. In F. Malerba, \& N. S. Vonortas (Eds.), Innovation Networks in Industries (Chapter 1). Cheltenham: Edward Elgar Publishing.

Malik, K. (2002). Aiding the Technology Manager: A Conceptual Model for Intra-Firm Technology Transfer. Technovation, 22, 427-436. https://doi.org/10.1016/S0166-4972(01)00030-X

March, J. G. (1991). Exploration and Exploitation in Organisational Learning. Organization Science, 2, 71-87. https://doi.org/10.1287/orsc.2.1.71

Mariasole, B., Varum, C., \& Pisictello L. (2013). The Impact of Public Support to SMEs' Outward FDI: Evidence from Italy. Journal of Small Business Management, 52, 22-38. https://doi.org/10.1111/jsbm.12029

Masum, M.I., \& Fernandez, A. (2008). Internationalization Process of SMEs: Strategies and Methods (pp. 20-23). Master Thesis, Västerås: International Business and Entrepreneurship.

Mazzarol, T., \& Reboud, S. (2008). The Role of Complementary Actors in the Development of Innovation in Small Firms. International Journal of Innovation Management, 12, 223-253. https://doi.org/10.1142/S1363919608001960

McAdam, M., Miller, K., \& McAdam, R. (2018). Understanding Quadruple Helix Relationships of University Technology Commercialisation: A Micro-Level Approach. Studies in Higher Education, 43, 1058-1073.

https://doi.org/10.1080/03075079.2016.1212328

Meissner, F. (1988). Technology Transfer in the Developing World: The Case of the Chile Foundation. Westport, CT: Praeger.

Meyer-Krahmer, F., \& Schmoch, U. (1998). Science-Based Technologies: University-Industry Interactions in Four Fields. Research Policy, 27, 835-851. https://doi.org/10.1016/S0048-7333(98)00094-8

Miesenbock, K. J. (1988). Small Businesses and Exporting: A Literature Review. International Small Business Journal, 6, 42-61. https://doi.org/10.1177/026624268800600204

Mohannak, K. (2007). Innovation Networks and Capability Building in the Australian High-Technology SMEs. European Journal of Innovation Management, 10, 236-251. https://doi.org/10.1108/14601060710745279

Molina-Morales, F. X., \& Martinez-Fernandez, M. T. (2010). Social Networks: Effects of Social Capital on Firm Innovation. Journal of Small Business Management, 48, 258-279. https://doi.org/10.1111/j.1540-627X.2010.00294.x

Mom, T. J. M., Oshri, I., \& Volberda, H. W. (2012). The Skills Base of Technology Transfer Professionals. Technology Analysis \& Strategic Management, 24, 871-891. https://doi.org/10.1080/09537325.2012.718663

Morgan, D. L. (1998). The Focus Group Guide Book. London: Sage. https://doi.org/10.4135/9781483328164

Morrissey, M. T., \& Almonacid, S. (2005). Rethinking Technology Transfer. Journal of Food Engineering, 67, 135-145. https://doi.org/10.1016/j.jfoodeng.2004.05.057

Mtigwe, B. (2006). Theoretical Milestones in International Business: The Journey to International Entrepreneurship Theory. Journal of International Entrepreneurship, 4, 5-25. https://doi.org/10.1007/s10843-006-5872-5

Nahapiet, J., \& Ghoshal, S. (1998). Social Capital, Intellectual Capital, and the Organization Advantage. Academy of Management Review, 23, 242-266. https://doi.org/10.5465/amr.1998.533225

Nidumolu, R., Prahalad, C. K., \& Rangaswami, M. R. (2009). Why Sustainability Is Now 
the Key Driver of Innovation. Harvard Business Review, 82, 57-67.

Nieman, G. (2006). Small Business Management: A South African Approach. Pretoria: Van Schaik.

Nooteboom, B. (1994). Innovation and Diffusion in Small Firms: Theory and Evidence. Small Business Economics, 6, 327-347. https://doi.org/10.1007/BF01065137

Norrman, C. (2008) Entrepreneurship Policy: Public Support for Technology-Based Ventures. PhD Dissertation, No. 1175, Linköping: Linköping University.

OECD (Organization for Economic Co-Operation and Development) (2004). Promoting Entrepreneurship and Innovation in a Global Economy: Towards a More Responsible and Inclusive Globalization. 2nd OECD Conference of Ministers Responsible for Small and Medium Sized Enterprises (SME), Istanbul, 3-5 June 2004, 9.

OECD (Organization for Economic Co-Operation and Development) (2005). Oslo Manual: Guidelines for Collecting and Interpreting Innovation Data (3rd ed.). Paris: Organization for Economic Co-Operation and Development.

OECD (Organization for Economic Co-Operation and Development) (2007). Innovation and Growth: Rationale for an Innovative Strategy. Paris: Organization for Economic Co-Operation and Development. http://www.oecd.org/science/inno/39374789.pdf

OECD (Organization for Economic Co-Operation and Development) (2010). OECD Studies on SMEs and Entrepreneurship: SMEs, Entrepreneurship and Innovation. Paris: Organization for Economic Co-Operation and Development.

OECD (Organization for Economic Co-Operation and Development) (2017). Towards an OECD Strategy for SMEs. OECD Working Party on SMEs and Entrepreneurship, Paris: Organization for Economic Co-Operation and Development, unpublished.

Office of Quality Improvement (2007). Focus Groups: A Guide to Learning The Needs of Those We Serve. Version 2.0.

https://www.yumpu.com/en/document/read/49913368/focus-groups-a-guide-to-learni ng-the-needs-of-oqiwiscedu

Omta, S. W. F., \& Van Rossum, W. (1999). The Management of Social Capital in R \& D Collaborations. In: R. T. A. J. Leenders, \& S. M. Gabbay (Eds.), Corporate Social Capital and Liability (pp. 356-375). Boston, MA: Springer. https://doi.org/10.1007/978-1-4615-5027-3_20

Osman-Gani, A. A. M. (1999). International Technology Transfers for Competitive Advantage: A Conceptual Analysis of the Role of HRD. Competitiveness Review, 9, 9-18. https://doi.org/10.1108/eb046370

Penrose, E. (1959). The Theory of the Growth of the Firm. Oxford: Basil Blackwell.

Perkmann, M., \& Walsh, K. (2007). University-Industry Relationships and Open Innovation: Towards a Research Agenda. International Journal of Management Reviews, 9, 259-280. https://doi.org/10.1111/j.1468-2370.2007.00225.x

Perlmutter, H. V., \& Sagafi-Nejad, T. (1981). International Technology Transfer, Guidelines, Codes and Muffled Quadrilogue. Oxford: Pergamon Press Inc.

Pfeffer, J., \& Salancik, G. (1978). The External Control of Organizations: A Resource Dependence Perspective. New York, NY: Haper and Row Publishers.

Phillips, R. G. (2002). Technology Business Incubators: How Effective as Technology Transfer Mechanisms. Technology in Society, 24, 299-316.

https://doi.org/10.1016/S0160-791X(02)00010-6

Phills, J. A., Deiglmeier, K., \& Miller, D. T. (2008). Rediscovering Social Innovation. Stanford Social Innovation, 6, 34-43.

Pirolo, L., \& Presutti, M. (2010). The Impact of Social Capital on the Start-Ups' Perfor- 
mance Growth. Journal of Small Business Management, 48, 197-227. https://doi.org/10.1111/j.1540-627X.2010.00292.x

Pittaway, L., Robertson, M., Munir, K., Nenyer, D., \& Neely, A. (2004). Networking and Innovation: A Systematic Review of the Evidence. International Journal of Management Reviews, 5-6, 137-168. https://doi.org/10.1111/j.1460-8545.2004.00101.x

Poot, T., Faems, D. L. M., \& Vanhaverbeke, W. (2009). Toward a Dynamic Perspective on Open Innovation: A Longitudinal Assessment of the Adoption of Internal and External Innovation Strategies in the Netherlands. International Journal of Innovation Management, 13, 177-200. https://doi.org/10.1142/S136391960900225X

Powell, W., Koput, K., \& Smith-Doerr, L. (1996). Interorganizational Collaboration and the Locus of Innovation: Networks of Learning in Biotechnology. Administrative Science Quarterly, 41, 116-145. https://doi.org/10.2307/2393988

Premaratne, S. P. (2002). Entrepreneurial Networks and Small Business Development: The Case of Small Enterprises in Sri Lanka. Doctoral Thesis, Eindhoven: Eindhoven University of Technology.

Pugh, R. (2017). Universities and Economic Development in Lagging Regions: 'Triple Helix' Policy. Wales. Regional Studies, 51, 982-993. https://doi.org/10.1080/00343404.2016.1171306

Qian, G., \& Li, L. (2003). Profitability of Small and Medium-Sized Enterprises in High-Tech Industries: The Case for Biotechnology Industry. Strategic Management Journal, 24, 881-887. https://doi.org/10.1002/smj.344

Quinn, J. B. (2000). Outsourcing Innovation: The New Engine of Growth. Sloan Management Review, 41, 13-28.

Quinn, M. (2002). Qualitative Research \& Evaluation Methods (3rd ed.). Thousand Oaks, CA: Sage Publications.

Ramanathan, K. (1994). The Polytrophic Components of Manufacturing Technology. Technological Forecasting \& Social Change, 46, 221-258. https://doi.org/10.1016/0040-1625(94)90003-5

Randolph, J. (2009). A Guide to Writing the Dissertation Literature Review. Practical Assessment. Practical Assessment, Research, and Evaluation, 14, Article No. 13.

http://pareonline.net/getvn.asp? $\mathrm{v}=14 \& \mathrm{n}=13$ https://doi.org/10.7275/b0az-8t74

Reisman, A. (2005). Transfer of Technologies: A Cross-Disciplinary Taxonomy. Omega, 33, 189-202. https://doi.org/10.1016/j.omega.2004.04.004

Ritter, T., \& Gemünden, H. G. (2003). Network Competence: Its Impact on Innovation Success and Its Antecedents. Journal of Business Research, 56, 745-755. https://doi.org/10.1016/S0148-2963(01)00259-4

Robinson, R. B. (1982). The Importance of "Outsiders" in Small Firm Strategic Planning. Academy of Management Journal, 25, 80-93. https://doi.org/10.5465/256025

Robinson, R. D. (1991). International Technology Communication in the Context of Corporate Strategic Decision-Making. In: R.D. Robinson (Ed.), The International Communication of Technology: A Book of Readings (pp. 28). London: Taylor \& Francis.

Rodan, S. (2010). Structural Holes and Managerial Performance: Identifying the Underlying Mechanisms. Social Networks, 32, 168-179.

https://doi.org/10.1016/j.socnet.2009.11.002

Rogers, M. (2004). Networks, Firm Size and Innovation. Small Business Economics, 22, 141-153. https://doi.org/10.1023/B:SBEJ.0000014451.99047.69

Romano, C. A. (1999). Identifying Factors Which Influence Product Innovation: A Case 
Study Approach. Journal of Management Studies, 27, 75-95.

https://doi.org/10.1023/B:SBEJ.0000014451.99047.69

Rosenbusch, N., Brinkmann, J., \& Bausch, A. (2011). Is Innovation Always Beneficial? A Meta-Analysis of the Relationship between Innovation and Performance in SMEs. Journal of Business Venturing, 26, 441-457. https://doi.org/10.1016/j.jbusvent.2009.12.002

Rothwell, R. (1991). External Networking and Innovation in Small and Medium-Sized Manufacturing Firms in Europe. Technovation, 11, 93-112. https://doi.org/10.1016/0166-4972(91)90040-B

Rothwell, R., \& Dodgson, M. (1994). Innovation and Size of Firm. In M. Dodgson, \& R. Roth-Well (Eds.), The Handbook of Industrial Innovation (pp. 310-342). Cheltenham: Edward Elgar.

Sahal, D. (1981). Alternative Conceptions of Technology. Research Policy, 10, 2-24. https://doi.org/10.1016/0048-7333(81)90008-1

Sahal, D. (1982). The Form of Technology. In Sahal, D (Eds.), The Transfer and Utilization of Technical Knowledge (pp. 125-139). Lexington, MA: Lexington Publishing.

Salanță, I. I., Beleiu, I. N., Mihaila, A., \& Crisan, E. L. (2018). Technology Transfer Related Concepts. Review of International Comparative Management, 19, 422-435.

Samli, C. (1985). Technology Transfee (pp. 155-156). Westport, CT: Quorum Books.

Sawyerr, O. O., McGee, J., \& Peterson, M. (2003). Perceived Uncertainty and Financial Performance in SMEs: The Role of Personal Networking Activities. International Small Business Journal, 21, 269-290. https://doi.org/10.1177/02662426030213002

Saxenian, A. (1990). Regional Networks and the Resurgence of Silicon Valley. California Management Review, 33, 89-112. https://doi.org/10.2307/41166640

Scalera, D., \& Zazzaro, A. (2009). Do Inter-Firm Networks Make Access to Finance Easier? Issues and Empirical Evidence. Working Paper No. 25, Cheltenham, UK: Money \& Finance Research. http://docs.dises.univpm.it/web/quaderni/pdfmofir/Mofir025.pdf

Schartinger, D., Rammer, C., Fischer, M. M., \& Fröhlich, J. (2002). Knowledge Interactions between Universities and Industry in Austria: Sectoral Patterns and Determinants. Research Policy, 31, 303-328. https://doi.org/10.1016/S0048-7333(01)00111-1

Schilling, M. A., \& Phelps, C. C. (2007). Interfirm Collaboration Networks: The Impact of Large-Scale Network Structure on Firm Innovation. Management Science, 53, 1113-1126. https://doi.org/10.1287/mnsc.1060.0624

Schumpeter, J. (1934). The Theory of Economic Development: An Inquiry into Profits, Capital, Credit, Interest, and the Business Cycle. Cambridge, MA: Harvard University.

Schumpeter, J. A. (1943). Capitalism, Socialism and Democracy. Crows Nest: Allan \& Unwin.

Secundo, G., Toma, A., Schiuma, G., \& Passiante, G. (2018). Knowledge Transfer in Open Innovation: A Classification Framework for Healthcare Ecosystems. Business Process Management Journal, 25, 144-163. https://doi.org/10.1108/BPMJ-06-2017-0173

Seibert, S. E., Kraimer, M. L., \& Liden, R. C. (2001). A Social Capital Theory of Career Success. Academy of Management Journal, 44, 219-237.

Sekaran, U. (1992). Research Methods for Business: A Skill-Building Approach (3rd ed.). Brisbane: John Wiley \& Sons Inc.

Shane, S., \& Venkataraman, S. (2000). The Promise of Entrepreneurship as a Field of Research. Academy of Management Review, 25, 217-226.

https://doi.org/10.5465/amr.2000.2791611 
Sorescu, A., Frambach, R. T., Singh, J., Rangaswamy, A., \& Bridges, C. (2011). Innovations in Retail Business Models. Journal of Retailing, 87, S3-S16. https://doi.org/10.1016/j.jretai.2011.04.005

Souder, W. E., Nashar, A. S., \& Padmanathan, V. (1990). A Guide to the Best Technology Transfer Practices. Journal of Technology Transfer, 15, 5-16. https://doi.org/10.1007/BF02377652

Spivey, W. A., Munson, J. M., Nelson, M. A., \& Dietrich, G. B. (1997). Coordinating the Technology Transfer and Transition of Information Technology: A Phenomenological Perspective. IEEE Transactions on Engineering Management, 44, 359-366. https://doi.org/10.1109/17.649866

Stabell, C. B., \& Fjeldstad, O. D. (1998). Configuring Value for Competitive Advantage: On Chains, Shops, and Networks. Strategic Management Journal, 19, 413-437. https://doi.org/10.1002/(SICI)1097-0266(199805)19:5\%3C413::AID-SMJ946\%3E3.0.C $\underline{\mathrm{O} ; 2-\mathrm{C}}$

Stewart, C. T., \& Nihei, Y. (1987). Technology Transfer and Human Factors. Lexington, MA: Lexington Books.

Sullivan, D., \& Marvel, M. (2011). How Entrepreneurs' Knowledge and Network Ties Relate to the Number of Employees in New SMEs. Journal of Small Business Management, 49, 185-206. https://doi.org/10.1111/j.1540-627X.2011.00321.x

Sundbo, J. (1998). The Theory of Innovation, Entrepreneurs, Technology and Strategy. Cheltenham: Edward Elgar.

Thorgren, S., Wincent, J., \& Örtqvist, D. (2009). Designing Interorganizational Networks for Innovation: An Empirical Examination of Network Configuration, Formation and Governance. Journal of Engineering and Technology Management, 26, 148-166. https://doi.org/10.1016/j.jengtecman.2009.06.006

Tsai, W., \& Ghoshal, S. (1998). Social Capital and Value Creation: The Role of Intrafirm Networks. The Academy of Management Journal, 41, 464-476.

Tyre, M. J. (1991). Managing the Introduction of New Process Technology: International Differences in a Multi-Plant Network. Research Policy, 20, 57-76. https://doi.org/10.1016/0048-7333(91)90084-4

Urban, G. L., Weinberg, B., \& Hauser, J. R. (1996). Premarket Forecasting of Really New Products. Journal of Marketing, 60, 47-60. https://doi.org/10.1177/002224299606000105

Uzzi, B. (1997). Social Structure and Competition in Inter-Firm Networks: The Paradox of Embeddedness. Administrative Science Quarterly, 42, 35-67. https://doi.org/10.2307/2393808

Vac, C. S., \& Fitiu, A. (2017). Building Sustainable Development through Technology Transfer in a Romanian University. Sustainability, 9, Article No. 2042. https://doi.org/10.3390/su9112042

Van de Ven, A. H. (1986). Central Problems in the Management of Innovation. Management Science, 32, 590-607. https://doi.org/10.1287/mnsc.32.5.590

Van de Vrande, V., De Jong, J., Vanhaverbeke, W., \& De Rochemont, M. (2009). Open Innovation in SMEs: Trends, Motives and Management Challenges. Technovation, 29, 423-437. https://doi.org/10.1016/j.technovation.2008.10.001

Van Gigch, J. P. (1978). Applied General Systems Theory. New York, NY: Harper \& Row.

Varadarajan, R. (2017). Innovating for Sustainability: A Framework for Sustainable Innovations and a Model of Sustainable Innovations Orientation. Journal of the Academy of Marketing Science, 45, 14-36. https://doi.org/10.1007/s11747-015-0461-6 
Varadarajan, R. (2018). Innovation, Innovation Strategy, and Strategic Innovation. Innovation and Strategy. Innovation and Strategy, 15, 143-166. https://doi.org/10.1108/S1548-643520180000015007

Vermeulen, P. A. M., DeJong, J. P. J., \& O’Shaughnessy, K. C. (2005). Identifying Key Determinants for New Product Introductions and Firm Performance in Small Service firms. The Service Industries Journal, 25, 625-640. https://doi.org/10.1080/02642060500100783

Villani, E., Rasmussen, E., \& Grimaldi, R. (2017). How Intermediary Organizations Facilitate University- Industry Technology Transfer: A Proximity Approach. Technological Forecasting and Social Change, 114, 86-102. https://doi.org/10.1016/j.techfore.2016.06.004

Virkkala, S., Mäenpää A., \& Mariussen A. (2017). A Connectivity Model as a Potential Tool for Smart Specialization Strategies. European Planning Studies, 25, 661-679. https://doi.org/10.1080/09654313.2017.1283391

Welch, L., \& Luostarinen, R. (1988). Internationalization Evolution of a Concept. Journal of General Management, 14, 34-55. https://doi.org/10.1177/030630708801400203

West, M. A., \& Anderson, N. R. (1996). Innovation in Top Management teams. Journal of Applied Psychology, 81, 680-693. https://doi.org/10.1037/0021-9010.81.6.680

Williamson, O.E. (1985). The Economic Institutions of Capitalism. New York, NY: Free Press.

Wolff, J. A., \& Pett, T. L. (2006). Small-Firm Performance: Modeling the Role of the Product and Process Improvements. Journal of Small Business Management, 44, 268-284. https://doi.org/10.1111/j.1540-627X.2006.00167.x

Yin, R.K. (2003). Case Study Research: Design \& Methods (3rd ed.). Thousand Oaks, CA: Sage Publications Inc.

Zain, M., \& Ng, S. I. (2006). The Impacts of Network Relationships on SMEs' Internationalization Process. Thunderbird International Business Review, 48, 183-205. https://doi.org/10.1002/tie.20092

Zaltman, G., Duncan, R., \& Holbek, J. (1973). Innovations and Organizations. New York, NY: John Wiley.

Zeng, S. X., Xie, X. M., \& Tam, C. M. (2010). Relationship between Cooperation Networks and Innovation Performance of SMEs. Technovation, 30, 181-194. https://doi.org/10.1016/j.technovation.2009.08.003

Zhao, L., \& Reisman, A. (1992). Toward Meta Research on Technology Transfer. IEEE Transactions on Engineering Management, 39, 13-21. https://doi.org/10.1109/17.119659 